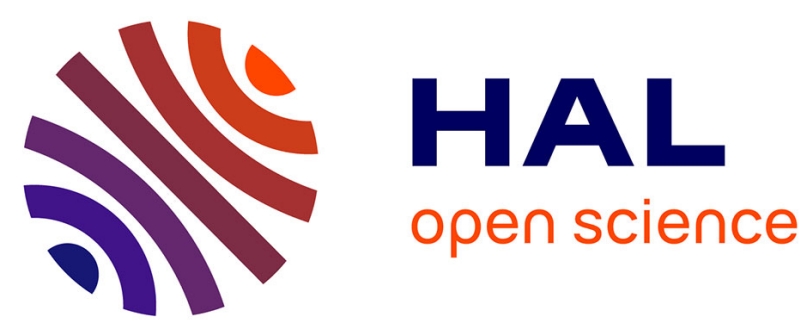

\title{
Geyserite in Hot-Spring Siliceous Sinter: Window on Earth's Hottest Terrestrial (Paleo)environment and its Extreme Life
}

Kathleen A. Campbell, Diego M. Guido, Pascale Gautret, Frédéric Foucher, Claire Ramboz, Frances Westall

\section{To cite this version:}

Kathleen A. Campbell, Diego M. Guido, Pascale Gautret, Frédéric Foucher, Claire Ramboz, et al.. Geyserite in Hot-Spring Siliceous Sinter: Window on Earth's Hottest Terrestrial (Paleo)environment and its Extreme Life. Earth-Science Reviews, 2015, 148, pp.44-64. 10.1016/j.earscirev.2015.05.009 . insu-01163128

\section{HAL Id: insu-01163128 \\ https://hal-insu.archives-ouvertes.fr/insu-01163128}

Submitted on 12 Jun 2015

HAL is a multi-disciplinary open access archive for the deposit and dissemination of scientific research documents, whether they are published or not. The documents may come from teaching and research institutions in France or abroad, or from public or private research centers.
L'archive ouverte pluridisciplinaire HAL, est destinée au dépôt et à la diffusion de documents scientifiques de niveau recherche, publiés ou non, émanant des établissements d'enseignement et de recherche français ou étrangers, des laboratoires publics ou privés. 


\section{Accepted Manuscript}

Geyserite in Hot-Spring Siliceous Sinter: Window on Earth's Hottest Terrestrial (Paleo)environment and its Extreme Life

Kathleen A. Campbell, Diego M. Guido, Pascale Gautret, Frédéric Foucher, Claire Ramboz, Frances Westall

PII:

S0012-8252(15)00092-6

DOI: $\quad$ doi: $10.1016 /$ j.earscirev.2015.05.009

Reference: $\quad$ EARTH 2121

To appear in: $\quad$ Earth Science Reviews

Received date: 24 October 2014

Accepted date: 11 May 2015

Please cite this article as: Campbell, Kathleen A., Guido, Diego M., Gautret, Pascale, Foucher, Frédéric, Ramboz, Claire, Westall, Frances, Geyserite in Hot-Spring Siliceous Sinter: Window on Earth's Hottest Terrestrial (Paleo)environment and its Extreme Life, Earth Science Reviews (2015), doi: 10.1016/j.earscirev.2015.05.009

This is a PDF file of an unedited manuscript that has been accepted for publication. As a service to our customers we are providing this early version of the manuscript. The manuscript will undergo copyediting, typesetting, and review of the resulting proof before it is published in its final form. Please note that during the production process errors may be discovered which could affect the content, and all legal disclaimers that apply to the journal pertain. 


\section{Geyserite in Hot-Spring Siliceous Sinter: Window on Earth's}

\section{Hottest Terrestrial (Paleo)environment and its Extreme Life}

Kathleen A. Campbell ${ }^{* 1,2}$, Diego M. Guido ${ }^{3}$, Pascale Gautret ${ }^{4,5}$, Frédéric Foucher ${ }^{2}$, Claire Ramboz $^{4,5}$, and Frances Westall ${ }^{2}$

${ }^{1}$ School of Environment, University of Auckland, Private Bag 92019, Auckland 1142, New

Zealand

${ }^{2}$ Exobiology Research Group, Centre de Biophysique Moléculaire, CNRS, Rue Charles

Sadron, 45071 Orléans cedex 2, France

${ }^{3}$ CONICET-UNLP, Instituto de Recursos Minerales, Calle 64 Esquina 120, La Plata (1900), Argentina

${ }^{4}$ Université d'Orléans \& CNRS, ISTO, UMR 7327, 45071 Orléans, France

${ }^{5}$ BRGM, ISTO, UMR 7327, BP 36009, 45060 Orléans, France

*Corresponding author: ka.campbell@auckland.ac.nz; Tel.: +63-9-923-7418; FAX: +64-9$373-7435$. 


\section{Abstract}

Siliceous hot-spring deposits, or sinters, typically form in active, terrestrial (on land), volcanic terrains where magmatically heated waters circulating through the shallow crust emerge at the Earth's surface as silica-charged geothermal fluids. Geyserites are sinters affiliated with the highest temperature $\left(\sim 75-100{ }^{\circ} \mathrm{C}\right)$, natural geothermal fluid emissions, comprising localized, lithologically distinctive, hydrothermal silica precipitates that develop around geysers, spouters and spring-vents. They demarcate the position of hot-fluid upflow zones useful for geothermal energy and epithermal mineral prospecting. Near-vent areas also are "extreme environment" settings for the growth of microbial biofilms at near-boiling temperatures. Microbial biosignatures (e.g., characteristic silicified microbial textures, carbon isotopes, lipid biomarkers) may be extracted from modern geyserite. However, because of strong taphonomic filtering and subsequent diagenesis, fossils in geyserite are very rare in the pre-Quaternary sinter record which, in and of itself, is patchy in time and space back to about $400 \mathrm{Ma}$. Only a few old examples are known, such as geyserite reported from the Devonian Drummond Basin (Australia), Devonian Rhynie cherts (Scotland), and a new example described herein from the spectacularly well-preserved, Late Jurassic (150 Ma), Yellowstonestyle geothermal landscapes of Patagonia, Argentina. There, geyserite is associated with fossil vent-mounds and silicified hydrothermal breccias of the Claudia sinter, which is geologically related to the world-class Cerro Vanguardia gold/silver deposit of the Deseado Massif, a part of the Chon Aike siliceous large igneous province. Tubular, filament-like micro-inclusions from Claudia were studied using integrated petrographic and laser microRaman analysis, the results of which suggest a biological origin. The putative fossils are enclosed within nodular geyserite, a texture typical of subaerial near-vent conditions. Overall, this worldwide review of geyserite confirms its significance as a mineralizing geological 
archive reflecting the nature of Earth's highest temperature, habitable terrestrial sedimentary environment. Hot-spring depositional settings also may serve as analogs for early Earth paleoenvironments because of their elevated temperature of formation, rapid mineralization by silica, and morphologically comparable carbonaceous material sourced from prokaryotes adapted to life at high temperatures.

Keywords: Geyserite, Sinter, Hydrothermal silica, Stromatolite, Hot springs, Geothermal, Fossil microbes, Early life

\section{Introduction}

Geyserite - a dense, finely laminated type of opaline silica deposit (sinter) formed in terrestrial (on land) hot springs - is spatially restricted to geysers, spouters and spring-vent areas splashed or submerged by near-boiling waters $\left(>\sim 75-100{ }^{\circ} \mathrm{C}\right.$; Fig. 1; White et al., 1964; Walter, 1976a). Depending on local conditions around the spring-vent or geyser, laminated siliceous precipitates build up into distinctive knobby, botryoidal, columnar, or wavy stratiform geyserite similar in appearance to stromatolites (Fig. 1; Walter, 1976a; Braunstein and Lowe, 2001). Thermophilic microbial biofilms of mostly filaments, as well as rods and coccoids, are adapted to living in present-day, near-vent fluids and affix to actively silicifying surfaces (e.g., Bott and Brock, 1969; Brock et al., 1971; Reysenbach et al., 1994). However, high-temperature biofilms may not preserve well upon lithification, and thus geyserite has been considered to be an abiogenic stromatolite-like deposit (Allen, 1934; Walter, 1976a, b).

Nonetheless for more than 60 years, geyserite and siliceous sinter have been compared to fossiliferous Precambrian cherts as representative "extreme environment" analogs for early life habitats (e.g., Tyler and Barghoorn, 1954; Walter, 1972; Maliva et al., 2005; Djokic et al., 
2014). Recent studies have verified the association of microbial filaments preserved in some modern geyserite (e.g., Cady et al., 1995; Jones and Renaut, 2003), but whether they grew at very high temperatures is open to debate because of dramatic fluctuations in near-vent environmental conditions (Braunstein and Lowe, 2001; Jones et al., 2003; Currie, 2005). In general, geyserite and other types of sinter indicate hot-fluid upflow areas intersecting the Earth's surface at locations closely correlated with structural trends, and hence they are relevant for prospecting for epithermal minerals and geothermal energy resources (Sillitoe, 1993; Guido and Campbell, 2011, 2014; Lynne, 2012). With respect to the geological record of geyserite, old examples are rare (Fig. 2) and those containing pre-Quaternary fossils are non-existent. This paper reviews: (1) the character and spatiotemporal distribution of geyseritic sinters; (2) whether geyserites may be considered a reliable indicator of hightemperature, terrstrial hot-spring activity in the geological record; (3) geyserites as possible stromatolites; and (4) their utility as extreme environment analogs in the search for Earth's earliest fossils and for life on other planets. A new Jurassic ( 150 Ma) geyseritic sinter discovery (Guido and Campbell, 2014), situated in an epithermal gold and silver mining district in Argentina, also is presented as a detailed case study in order to evaluate the nature and preservation of fossil geyserite - including possible entombed filaments - from the micron-scale to its regional geological context.

\section{Overview of Hydrothermal Systems and Geyserite}

\subsection{Importance of hydrothermal systems}

Hot springs on land and in the sea are extreme terrestrial environments, harboring the highest temperature life forms - hyperthermophilic microbes - known on Earth (Reysenbach 
et al., 2001; Capece et al., 2013). Marine hydrothermal vents at oceanic spreading centers contain prokaryotes living under high pressures at up to $122^{\circ} \mathrm{C}$ (e.g., Keshefi and Lovley, 2003; Takai et al., 2008). Depending on their fluid chemistry, terrestrial hot springs on land host acid- or alkaline-loving microbes at near-boiling to ambient temperature conditions (Capece et al., 2013). While deep-sea, "black smoker," massive sulfide deposits with entombed microfossils occur in the geological record as far back as the Archean Eon $(3.2 \mathrm{Ga}$; Rasmussen, 2000; Kiyokawa et al., 2006), siliceous hot-spring deposits (sinter) are only as old as the Devonian ( 400 Ma; Rice and Trewin, 1988; Cuneen and Sillitoe, 1989). Older sinter is likely but has yet to be recognized. Because proximal vent areas of terrestrial hydrothermal systems host extreme life (e.g., Brock et al., 1971; Reysenbach et al., 1994; Takacs et al., 2001; Blank et al., 2002), and often are mineralizing (section 2.2), they have been suggested as analog settings for the preservation of early life on Earth and possibly Mars (Bock and Goode, 1996; Farmer and Des Marais, 1999; Farmer, 2000; Cady et al., 2003; Konhauser et al., 2003). Indeed, possible siliceous hot-spring deposits recently have been discovered on Mars (Squyres et al., 2008; Ruff et al., 2011). Moreover, terrestrial hyperthermophiles occupy deep phylogenetic branches (e.g., Reysenbach et al., 1994; Barion et al., 2007). Thus, their heat tolerance has been considered an adaptational remnant of elevated surface temperatures during early bombardment, a time during which life had most likely emerged on Earth (Farmer, 2000; Nisbet and Sleep, 2001), although mesophilic origins of life also have been proposed (e.g., Boussau et al., 2008). Determining the upper temperature limit of terrestrial life, past and present, provides boundary conditions around where and when life may have evolved on a hotter early Earth, the depth to which subsurface microbial worlds may exist, and whether exoplanets and moons may be habitable (Kashefi and Lovley, 2003). 
Hot-spring sinters are utilized in prospecting for extractable heat energy and precious metals at shallow crustal depths (e.g., Weissberg, 1969; Rice and Trewin, 1988; Sillitoe, 1993; Fournier et al., 1994; Zimmerman and Larson, 1994; Sherlock et al., 1995; Vikre, 2007; Guido and Campbell, 2011; Lynne, 2012; Rowland and Simmons, 2012). Their spatial association with fluid-transporting faults and hydrothermal eruption breccias, their elemental and isotopic compositions, and their (paleo)environmentally sensitive textures may point to shallow-depth epithermal mineralization, as well as to the relative volumes of water available for paleo-water-rock interactions that may have concentrated ores or reflect paleo-climatic conditions (e.g., Goldie, 1985; Sturchio et al., 1993; McKenzie et al., 2001; Darling and Spiro, 2007; Guido and Campbell, 2014).

\subsection{Geyserites as high-temperature deposits of terrestrial hot springs}

Dynamic, convective, high-enthalpy geothermal systems predominantly form in volcanic terrains where magmatic heat drives groundwater circulation and water-rock interactions, producing mainly liquid-dominated, alkali chloride geothermal fluids of nearneutral pH with high dissolved silica content (Henley and Ellis, 1983; Renaut and Jones, 2011). Static geothermal systems also are known from terrains without surface evidence for volcanism, heated by above-average conductive heat flow through the crust (Renaut and Jones, 2011). Acidic $\left(\mathrm{H}_{2} \mathrm{~S}\right)$, steam-heated groundwaters form in many geothermal areas, manifesting acid or mixed acid-sulfate-chloride springs (Ellis and Wilson, 1961; Henley and Ellis, 1983; Renaut and Jones, 2011), the latter of which may form thin (few cms to dm), "acid sinters" with distinct textures and affiliated acidophilic biotas (e.g., Jones et al., 2000; Schinteie et al., 2007). 
Silica-charged, alkali chloride geothermal systems of near-neutral $\mathrm{pH}$ are typified by very high-temperature $\left(>\sim 75-100^{\circ} \mathrm{C}\right)$ spring-vents, spouters or geysers, the immediately surrounding areas of which $(<\sim 15 \mathrm{~m})$ are draped with a variety of geyseritic sinter textures (Fig. 1) developed under surging, splashing or spraying conditions (Walter, 1976a; Braunstein and Lowe, 2003). Furthermore, the affiliated, cooling geothermal fluid discharge areas ( $<75^{\circ} \mathrm{C}$ to ambient) form thick (m's to 10 's of m's) sinter-apron terraces, spring-fed thermal pools and creeks, and geothermally influenced marshes (Fig. 2), with a decrease seen in the abundance of (hyper)thermophilic bacteria and archaea with decreasing temperature, and a concomitant increase in mesophilic cyanobacterial and eukaryotic biotic components along this decreasing thermal gradient (Walter 1976b; Cady and Farmer, 1996; Jones et al., 1997a, b; Lowe et al., 2001; Guidry and Chafetz, 2003; Guido and Campbell, 2011; Handley and Campbell, 2011; Renaut and Jones, 2011). Microbes serve as templates upon which spring-related silicification or calcification takes place, forming an array of distinctive and recurring stromatolitic textures in geothermal sinter or travertine, respectively (Table 1; Fig. 2; Walter, 1976b; Cady and Farmer, 1996; Pentecost, 2005).

Strongly localized geyserite distributions are delineated by vent location - commonly structurally controlled - as well as by temperature of the emitted geothermal fluid, its discharge volume, evaporation rate, $\mathrm{pH}$, and dissolved silica concentration (Walter et al., 1976a; Braunstein and Lowe, 2001; Boudreau and Lynne, 2012). Based on activity and eruptive style, Braunstein and Lowe (2001) identified several classes of geysers in alkaline spring-vent areas at Yellowstone National Park (Wyoming, U.S.A.), from boiling to nonboiling, and from non-surging to vigorously so (e.g., Fig. 1A, 1C). Rapid cooling and evaporation at geyser and vent discharge points cause oversaturation with respect to amorphous silica, leading to precipitation of hydrous, non-crystalline opal-A in an assortment of distinctive deposit geometries, macro-morphologies and microbanded fabrics (Krauskopf, 
1956; White et al., 1956; Walter, 1976a; Rimstidt and Cole, 1983; Fournier, 1985; Göttlicher et al., 1998; Lowe and Braunstein, 2003; Jones and Renaut, 2004; Boudreau and Lynne, 2012). Physical variations in vent-area hydrodynamics within subaqueous and subaerial environments produce stratiform, spicular, beaded, nodular and columnar geyserite varieties (Fig. 1; Walter, 1976a, b; Braunstein and Lowe, 2001). Over time, structural water loss during silica phase mineral diagenesis induces recrystallization of originally opaline sinters to quartz or, less commonly, chalcedony (White et al., 1964; Göttlicher et al., 1998; Herdianita et al., 2000; Rodgers et al., 2004). While geyser mounds and/or geyseritic macrotextures occasionally are reported from pre-Quaternary sinters (e.g., Trewin, 1993; Walter et al., 1996; Guido and Campbell, 2009), their microtextural features are usually not well preserved and are therefore rarely studied.

\subsection{Geyserites as abiogenic or biogenic stromatolites of terrestrial hot springs}

It has been debated whether actively forming geyserites incorporate and preserve signals of high-temperature-adapted micro-organisms into a lasting sinter record. Following the reasoning of McLoughlin et al. (2008), we adopt a non-genetic definition of a stromatolite (Semikhatov et al., 1979) as "an attached, laminated, lithified, sedimentary growth structure, accretionary away from a point or limited surface of initiation." The relative contribution of abiotic or biotic influence for a particular stromatolite must therefore be assessed on a caseby-case basis. This may be quite difficult to determine in environmental settings where biosignatures are cryptic or easily destroyed by taphonomic and diagenetic processes (see also section 4.2). Early reports asserted geyserites to be abiogenic, stromatolite "look-alikes" (Allen, 1934; Walter, 1976a), also termed stromatoloids (Oehler, 1975; Krumbein, 1983). Later ultrastructural microscopy studies revealed entombed microbial components in several 
modern examples (e.g., Cady et al., 1995; Cady and Farmer, 1996; Jones et al., 1997a, b, 2001; Lowe and Braunstein, 2003; Jones and Renaut, 2003; Cady, 2008; Garcia-Valles et al., 2008; Urusov et al., 2008). Microbiological investigations have identified biofilms of nonphotosynthetic, heterotrophic and chemolithotrophic bacteria and archaea - mainly filaments but also some coccoids and rods - in slightly alkaline spring waters hotter than about $75^{\circ} \mathrm{C}$ (e.g., Setchell, 1903; Brock, 1967a; Bott and Brock, 1969; Reysenbach et al., 1994; Huber et al., 1998; Rothschild and Mancinelli, 2001; Takacs et al., 2001; Blank et al., 2002; Cady, 2008). This is the upper limit of temperature tolerance for photosynthetic bacteria, which flourish as luxuriant and colorful mats in cooler $\left(<\sim 70-30{ }^{\circ} \mathrm{C}\right)$, more distal sinter-apron terraces, pools and outflow channels (e.g., Davis, 1897; Brock and Brock, 1966, 1971; Brock, 1967a, b; Walter et al., 1972; Walter, 1976b; Brock, 1978; Cady and Farmer, 1996; Lowe et al., 2001). With their thick, durable polysaccharide sheaths, cyanobacteria in these cooler geothermal settings generally are resistant to degradation, and thus typically silicify and fossilize well into microbial sinter (Table 1; Horodyski et al., 1977; Jones et al., 2001a; Konhauser et al., 2003). In contrast, for hyperthermophilic biofilms growing in near-boiling springs (e.g., Reysenbach et al., 1994; Blank et al., 2002), their preservation appears to be controlled by relative timing of mineralization, with subsequent visibility commonly masked by secondary silica infilling (Cady, 2008; Urusov et al., 2008; Peng and Jones, 2012). Recently the usefulness of geyserite as an unequivocal indicator of high-temperature spring (paleo)environments (White et al., 1964) has been called into question with the discovery of low-temperature microbes in a geyser mound from a modern New Zealand hot spring (Jones et al., 2003), analyzed further in section 4.2.

\subsection{Geyserite in the geological record}


Figure 3 illustrates the global distribution of reported geyserite occurrences in Devonian to present-day siliceous hot-spring deposits (sinter). While the presence of geyserite has been mentioned in a few reports on fossil sinters (e.g., Devonian - Trewin, 1993; 1996; Walter et al., 1996; Fayers and Trewin, 2003; Miocene-Hamilton, 2014; Quaternary - Sherlock et al., 1995; Hinman and Walter, 2005; Darling and Spiro, 2007), all in-depth analyses to date have been conducted on Recent and Subrecent geyserite (e.g., Walter, 1976a, b; Cady and Farmer, 1996; Jones et al., 1997a; Braunstein and Lowe, 2001; Jones et al., 2001b; Lowe et al., 2001; Guidry and Chafetz, 2003; Jones and Renaut, 2003, 2004; Jones et al., 2003; Lowe and Braunstein, 2003; Urusov et al., 2008; Isaenko et al., 2011; Boudreau and Lynne, 2012; Watts-Henwood, 2015). This discrepancy is likely due, in part, to the poor preservation state of many old (pre-Quaternary) sinters, where fine textures and other attributes have become obscured owing to post-depositional weathering and diagenetic recrystallization (e.g., Walter et al., 1996; Hinman and Walter, 2005). In addition, vent deposits constitute a volumetrically minor component of any given hot-spring system compared to the surrounding, silicifying discharge apron and geothermally influenced marsh areas (Weed, 1889; Walter, 1976b), and hence are less likely to be preserved in the geological record. Finally, old geyserite is also rare because of the destructive nature of the geological setting in which it commonly forms - i.e. volcanic terrains replete with explosive volcanism and hydrothermal events - such as was shown by the obliteration of New Zealand's famous Pink and White Terraces in the Tarawera eruption of 1886 (Simmons et al., 1993). Moreover, most of Yellowstone's post-caldera history of hydrothermal activity has either been buried by lavas or eroded away by glaciers, with only the past 13,000 years preserved, and hence the paucity of old sinters in this region (Hurwitz and Lowenstern, 2014).

In this review evaluating the origin, nature and distribution of geyserite, we also present the first detailed study of pre-Quaternary geyserites (section 3). They are in sinters of 
Late Jurassic age from the Claudia deposit, Deseado Massif mining district, Chon Aike large silicic igneous province, Argentine Patagonia (Fig. 4). The Claudia geothermal sinters and travertines, and geologically affiliated Cerro Vanguardia epithermal gold and silver veins, constitute an exceptionally large (up to $1000 \mathrm{~km}^{2}$ ) and well-exposed fossil hydrothermal system (Figs. 4, 5; Guido and Campbell, 2014). Claudia sinter facies also encompass a complete paleoenvironmental gradient (sensu Brock and Brock, 1966; Walter, 1976b; Cady and Farmer, 1996; Lowe et al., 2001), which is not commonly preserved in the geological record of hot-spring deposits. Claudia deposits range from high-temperature vent and proximal apron facies $\left(\sim 100-70{ }^{\circ} \mathrm{C}\right)$, to moderately high- to low-temperature $\left(<70-30{ }^{\circ} \mathrm{C}\right)$ discharge aprons and pond facies, to tepid-ambient geothermally influenced marsh settings (cf. Fig. 2; Guido and Campbell, 2011; 2014). As detailed herein, Claudia geyserites also contain rare associated biomorphs. Hence, they afford a view on the character, preservation and diagenesis of a 150-m.y.-old siliceous sedimentary facies indicative of the hottest inhabitable, mineralizing, terrestrial (land-based) environment on Earth. This review also has the potential to aid in a better understanding of some Precambrian "abiogenic stromatolites" (sensu Walter, 1972; Pouba, 1978; Sommers and Awramik, 1996; Djokic et al., 2014), a number of which are morphologically similar to geyserites and have been suggested to have been hydrothermally influenced during their formation (section 4.3).

\section{Case study: Late Jurassic geyserite from Patagonia, Argentinea}

In the Middle-Late Jurassic, the Deseado Massif province $\left(60,000 \mathrm{~km}^{2}\right)$ of southern Patagonia, Argentina, exhibited mostly rhyolitic and andesitic volcanism (Fig. 4) owing to crustal thinning in a diffuse, extensional back arc setting associated with the break-up of Gondwana and opening of the southern Atlantic Ocean (Pankhurst et al., 2000; Riley et al., 
2001; Richardson and Underhill, 2002). Widespread hydrothermal activity was affiliated with the mature (quiescent) volcanic phase during the Late Jurassic ( 178-151 Ma; Pankhurst et al., 2000), which produced metalliferous deposits (largely Ag, Au) at depth, extensive silicification, and geothermal manifestations at the surface (Schalamuk et al., 1997; Guido and Campbell, 2011). More than 50 Jurassic metalliferous occurrences, mainly classified as the epithermal low-sulfidation type, are distributed over a $400 \times 250 \mathrm{~km}$ area within the massif (Schalamuk et al., 1997). Five mines have been active in the region, such as Cerro Vanguardia situated $20 \mathrm{~km}$ to NW of Claudia (Figs. 4, 5), and several others are under advanced development. A fortuitous geological history in the Deseado Massif region first preserved and then exhumed this largely structurally undisturbed volcanic terrain, providing an opportunity to explore Jurassic, Yellowstone-style geothermal landscapes and associated epithermal mineralization in their original contexts, from regional to micron scales (Guido and Campbell, 2011). In particular, during exploration and field reconnaissance surveys throughout the Deseado Massif, numerous near-intact, fossilized geothermal fields were discovered within volcaniclastic fluvio-lacustrine strata (Guido and Campbell, 2009, 2011, 2012, Guido et al., 2010), including the Claudia deposit (Fig. 4; Guido and Campbell, 2014). Geyseritic textures of the Claudia sinter deposit are exposed in spring-vent mound associations, or in scattered blocks affiliated with a silicified hydrothermal breccia and interpreted to represent erosional remnants of a former vent area (Guido and Campbell, 2014, their figs. 1-4, p. 62-66). The sinter deposits are situated in the southern part of the Claudia paleo-geothermal field (Fig. 5), at the intersection of three regionally significant, basementrelated, structural/magnetic lineaments (Guido and Campbell, 2014, their fig. 6, p. 68). In the Deseado Massif, fossil hot-spring deposits are geographically aligned with gold and silver epithermal deposits and magnetic anomalies that reflect large-scale structures (Guido and Campbell, 2011, their fig. 1, p. 37). Thus, the paleogeographic position and geologic context 
of the Claudia deposit highlight the general relationship of regional fractures controlling Late Jurassic thermal fluid ascent in the Deseado Massif (Guido and Campbell, 2011).

The field characteristics, macrotextures and microtextures of the Claudia geyserites are illustrated in Figures 6-10. In field context, siliceous vent mounds $(\sim 3 \mathrm{~m}$ high $\times 10-15 \mathrm{~m}$ diameter) cluster atop a present day and Jurassic topographic high (Fig. 6A, 6B), overlying a preserved stratigraphic sequence of interbedded travertines and sinters $(\sim 10-20 \mathrm{~m}$ thick) at the La Calandria Sur outcrop, which in total exposes a $130 \mathrm{~m} \times 10-50 \mathrm{~m}$ area of paleogeothermal activity (Guido and Campbell, 2014, their fig. 4A, p. 64). The Jurassic sinter mounds are of similar size and distribution compared to modern Yellowstone spring-vent mounds (cf. Fig. 6B, 6C). The Claudia mounds display a broadly knobby/macrobotryoidal outer form (Fig. 6D), and enclose cores of silicified breccias dissected by hollow, sinuous tubes, inferred as vent conduits (see also Guido and Campbell, 2014, their fig. 2D, p. 64), and analogous to modern New Zealand examples (e.g., Figs. 1B, 6E). Occasional, smooth, channel-like features ( $\sim 35 \mathrm{~cm}$ wide) occur on some mound surfaces (Fig. $6 \mathrm{~F})$, interpreted as proximal vent-discharge channels akin to those observed on New Zealand geyser vent mounds (Fig. 6G).

The Claudia geyserites exhibit stromatolite-like macrofabrics including branching columnar, pseudocolumnar nodular, and cumulate stratiform to nodular textures (sensu terminology used in Walter, 1976a, and Walter et al., 1992). The columns and nodules are made up of thin, dense, smooth, relatively even laminae $(5-50 \mu \mathrm{m}$ thick) and are morphologically similar to modern New Zealand geyserites (Fig. 7A-J). Some vent mounds also show 'ripple films' on their outer surfaces (Fig. 7K), which in Holocene spring-vent areas (Fig. 7L) are affiliated with proximal, very shallow surface discharges.

Some Claudia geyserite samples preserve microtextures analogous to present-day examples from Yellowstone and New Zealand (Fig. 8). For instance, columnar types are 
common (Fig. 8A, 8C; columns up to $3 \mathrm{~cm} \mathrm{long,} \mathrm{up} \mathrm{to} 1 \mathrm{~cm}$ wide), and nearly indistinguishable from New Zealand examples (Fig. 8B, 8D). In detail, branching is parallel to moderately divergent and bifurcating. Lateral, coalesced or anastomosed branching types occur in slender columns with laminae ranging from smooth and uniform to somewhat irregular. Occasional micro-cross-lamination and cornices and bridges are evident between some columns (e.g., Fig. 8A-D, 8I). In a few places, cores of gently convex, stacked, fine laminae are overlain by thin cortices of steeply convex laminae parallel to the outer surface of the core (sensu Jones and Renaut, 2003). Spicules (narrow columns up to $\sim 1.5 \mathrm{~cm}$ long, 0.5 to $1 \mathrm{~mm}$ in diameter) are evident in some samples (Fig. 8C). Quartz microtextures within the columnar geyserites are largely microcrystalline, with small patches of mesocrystalline quartz (cf. Maliva et al., 2005) demarcating primary or secondary porosity, either as small vugs surrounding columnar macrofabrics (Fig. 8H, 8I) or in thin horizons parallel to internal laminae (Fig. 8I, 8J). Another typical vent-related microtexture at Claudia is nodular geyserite (Fig. 7C), which in cross-section is mainly pseudocolumnar to cumulate (broadly wavy) (Figs. 7E, 8E), or stratiform. Quartz microtextures within the nodular geyserite also are mainly microcrystalline, with a few thin horizons comprising mesocrystalline quartz that delineate areas of primary or secondary porosity.

In a few places, the Claudia geyserite samples enclose bands or patches of dense and numerous tubular microstructural features (Fig. 8E-G). The tubular structures with dark fill (reddish brown, brown or black in color), or their transparent molds, are $\sim 5 \mu \mathrm{m}$ in diameter and up to $1.5 \mathrm{~mm}$ long. They are arranged in dense, pillar-like aggregations forming slightly radially oriented groupings within pseudocolumnar nodules (Fig. 8F, 8G). Laser microRaman mapping of the dark fill of several tubular structures revealed the presence of carbon, and in one sample a patchy association with anatase and carbon (Fig. 9A, 9B). We infer that the tubular structures represent fossilized filamentous microbes. Anatase $\left(\mathrm{TiO}_{2}\right)$ is a common 
mineral in volcanic terrains. It may form during destruction of biotite in volcanic host rocks by migrating acidic fluids associated with high-sulfidation mineralization (Corbett, 2002), or may develop during hydrothermal alteration (Franchini et al., 2011).

\section{Discussion and synthesis}

In section 4.1, the lithofacies associations of geyserite are reviewed and discussed with respect to their utility as high-temperature spring indicators. In section 4.2 , the notion of geyserites as abiogenic versus biogenic microstromatolites is evaluated. In section 4.3, we summarize comparisons of sinter and geyseritic textures to Precambrian siliceous biosignatures, and examine the problem of stromatoloids, or abiogenic "stromatolites," terms which have been applied both to the many geyserites that do not preserve morphological biosignatures and to certain Precambrian microfabrics to which geyserites have been likened. We suggest that the Late Jurassic Argentine geyserites (section 3) may serve as comparative "stepping stones" into the deep time geological record, from Quaternary sinters to Devonian geothermal systems, to Precambrian shallow-marine strata containing evidence for hydrothermal influence and silicified biosignatures.

\subsection{Geyserite as a lithofacies indicator for high-temperature terrestrial hot springs}

The textural and facies associations of geyserite in published reports are evaluated here to assess whether the lithological features of fossil examples, including the Jurassic Claudia material described in detail in section 3, are consistent with modern deposits known to have formed in terrestrial springs of very high temperatures $\left(>75^{\circ} \mathrm{C}\right)$. Walter $(1976 \mathrm{a})$ and Jones and Renaut (2003) reviewed early mention of geyserite in the literature. White et al. 
(1964, p. B31) formally defined geyserite as microbanded opaline sinter of colloform, botryoidal or knobby habit, and stated that it "should be distinguished from other types of sinter because of its usefulness in recognizing proximity to former spring vents and fissures." Subsequent detailed study of modern vent-area hydrodynamics, coupled with petrographic analyses of Recent and Subrecent geyserites from Yellowstone National Park (Wyoming, U.S.A.) and the Taupo Volcanic Zone (New Zealand), have established that spring ventrelated geyserite develops in three zones. These are: (1) finely stratiform geyserite, deposited in fully subaqueous conditions within vent pools and channel floors (Fig. 1F, 1G); (2) spicular geyserite developing on poolward, subaerial levee/rim margins periodically splashed by surge and spray (Fig. 1D-F); and (3) complex varieties (e.g., Fig. 1D-F, 1H, 1J) of columnar, pseudocolumnar nodular, and beaded geyserite in subaerial pool-rim and proximal slope areas wetted occasionally by overflow and surging of hot waters of varied turbulence to form either broad, low botryoidal siliceous masses (e.g., Fig. 1B), or low flat areas accumulating siliceous "beads" of ooids and pisoids (e.g., Walter, 1972; Walter, 1976a; Braunstein and Lowe, 2001; Lowe and Braunstein, 2003; Jones and Renaut, 2003). Geyser beads grow in areas of vigorous turbulence (Walter, 1976a). It has been noted that geyserite spicules (Fig. 1D-F; typically $0.5-1 \mathrm{~mm}$ diameter, up to $3 \mathrm{~cm}$ long) and geyserite columns (Fig. 1D, 1J; up to $1.5 \mathrm{~cm}$ wide, up to $4 \mathrm{~cm}$ high) exhibit a size gradation that blurs their distinction (Jones and Renaut, 2003). In reviewing geyserite textures for this contribution, we observed gradational transitions in morphology from wavy stratiform to spicular to bulbous to columnar to pseudocolumnar/nodular varieties (e.g. Figs. 1, 7, 8, 10). Spicules are somewhat delicate and can easily weather on dry, exposed sinter surfaces (Jones and Renaut, 2003), suggesting a possible taphonomic bias toward their destruction prior to incorporation into the geological record. In Claudia geyserite samples, spicules were uncommon (Figs. 8C, $10)$. 
In modern alkali-chloride spring settings of near-neutral $\mathrm{pH}$ waters, hot fluid emissions oversaturated in $\mathrm{Si}(>300 \mathrm{ppm}$ ) are locally transported from the vent to deposit geyserite via air-cooled spray, proximal channel run-off, surge oscillation in the surface level of source pool waters, or capillary rise through pores and deposition upon local substrates (Jones et al., 1997a; Jones and Renaut, 2003, 2004). Maximum thicknesses of macro-scale, botryoidal bedforms of geyserite (cf. Fig. 1B) reach approximately $2 \mathrm{~m}$, and accumulate $<15$ $\mathrm{m}$ distance from the vent at the point where splashes are frequent but also where the expelled fluids can evaporate before another splash occurs (Walter, 1976a; Boudreau and Lynne, 2012). The most rapid localized silica accretion occurs on the high points of rugose subaerial surfaces (i.e., preferential growth on the fast-drying tips of spicules and columns), where hot fluids drain off quickly and evaporation of remaining droplets causes oversaturation of silicic acid $\left(\mathrm{H}_{4} \mathrm{SiO}_{4}\right)$, resulting in rapid precipitation of dense, monomeric, opaline silica (White et al., 1956; Walter, 1976a; Fournier, 1985; Göttlicher et al., 1998; Jones and Renaut, 2003; Lowe and Braunstein, 2003; Jones and Renaut, 2004; Boudreau and Lynne, 2012). By contrast, in subaqueous vent pools (Fig. 1G) or around acid-sulfate-chloride springs (Ellis and Wilson, 1961), geyserite forms sluggishly, owing to slower rates of polymerization/precipitation of dissolved silica in these settings (Walter, 1976a).

Modern geyserite displays a characteristic feature - dense, even, very fine (500 nm-4 $\mu \mathrm{m}$ thick), alternating light/dark laminae - which variously has been interpreted as demarcating annual silica accumulation, daily precipitation, or individual eruptive cycles (Walter, 1972; Walter, 1976a; Lowe and Braunstein, 2003; Jones and Renaut, 2004). In a study of modern New Zealand geyserite, Jones and Renaut (2004) found that dark laminae constitute "wet" opal (12-13 wt $\% \mathrm{H}_{2} \mathrm{O}+\mathrm{OH}$; initially deposited as a hydrous silica gel) and light laminae comprise "dry" opal (5-6 wt \% $\mathrm{H}_{2} \mathrm{O}+\mathrm{OH}$; formed by evaporation/desiccation of thin films of wet opal). These alternating dark and light laminae represent rapid vs. slow 
evaporation/precipitation, respectively. Variables in the local environment (e.g., shifts in discharge, humidity, evaporation rate, wind direction, gas emission flux, surface roughness, etc.) affect opal precipitation rates such that individual laminae do not appear to correlate directly with spring eruption cycles (Jones and Renaut, 2004). It is striking that the dimensions, morphologies and microtextures of the Late Jurassic Claudia geyserites are nearly identical to modern New Zealand geyserites (Figs. 6-8), implying a similar formation mechanism. Individual laminae in the Jurassic samples are somewhat thicker, and may be a product of diagenesis destroying the finer laminae typical of modern geyserites (Walter, 1976a). Moreover, while micro-cross-lamination has been reported as an important identifying feature of modern geyserites at Yellowstone (Walter, 1976a), it is not ubiquitous there, nor in New Zealand Subrecent and Recent geyserites (Jones and Renaut, 2003), nor in Jurassic Claudia geyserites. Under cross-polarized light microscopy, some relatively wellpreserved Claudia geyserite samples exhibit subtle differences in the orientations, local distributions and extinction patterns of interlocking, microcrystalline quartz crystals to reveal fine laminae, cornices and rare micro-cross-lamination that are not readily visible in planepolarized light (Fig. 8H-J).

The only reported occurrences of in situ geyserite in the geological record older than Quaternary age are the Late Jurassic Deseado Massif geyserites at Claudia (Guido and Campbell, 2014) and La Marciana (Guido and Campbell, 2009), Argentina, and the strongly recrystallized occurrences in the Devonian Drummond Basin sinters, Australia (Walter et al., 1996). Moreover, in the Devonian Windyfield chert, Scotland, a float block of nodular and spicular geyserite, as well as trenched subcrop and drill core samples of geyserite-mantled sandstone clasts and silicified sinter breccia, indicate higher temperature conditions than in the main Rhynie chert locality $700 \mathrm{~m}$ to the SW (Trewin, 1993; Fayers and Trewin, 2003). However, the Scottish sinters do not crop out at the surface and are intensely faulted (Trewin, 
1993); therefore, only spatially limited paleoenvironmental reconstructions are possible. It also has been observed that many reported sinters are actually silicified sediments (Sillitoe, 1993; Campbell et al., 2003) or silicified travertines, also known as pseudo-sinters (Guido and Campbell, 2012). Of the few in situ, Mesozoic and Paleozoic geyserites reported in the literature (Fig. 2), the deposit at La Marciana, Patagonia, is thickest ( $3 \mathrm{~m})$ near a paleo-vent area identified by structural mapping and textural indicators of paleo-flow direction, and marked by a silicified breccia inferred to have formed during hydrothermal eruption activity (Guido and Campbell, 2009). Geyserite microtextures have yet to be studied from this site, although the sinter appears to be recrystallized. At the NW end of the main outcrop of the Verbena sinter in the Australian Drummond Basin (Devonian), 7-8 m wide areas of coarsely botryoidal bedforms (10-20 $\mathrm{cm}$ diameter) of geyserite contain poorly preserved, fan-like aggregates of spicules of the same broad character as those found in modern, hightemperature spring-vent areas (Walter et al., 1996). Geyser bead macrotextures also are preserved. In comparison, Claudia geyserites are physically associated with preserved vent mounds (Fig. 6) in a structurally undisturbed paleo-geothermal landscape, or are found as scattered blocks adjacent to a silicified hydrothermal breccia that likely delineates a ventsource area (Guido and Campbell, 2014, their fig. 4A-B, p. 66). The petrographic features and microtextures of the Claudia geyserites (Fig. 8) are consistent with modern hydrothermal silica precipitation at geyser mounds and spring-vent areas. Collectively these few autochthonous, old geyserite occurrences of Mesozoic and Paleozoic age indicate a spatial restriction to proximal-vent lithofacies associations.

In summary, Walter $(1972 ; 1976 a)$ outlined criteria for the recognition of geyserite lithofacies in the geological record, which we review and expand on here. Diagnostic features visible in outcrop are spicular, nodular, bulbous, columnar, pseudocolumnar, beaded and/or cumulate stratiform textures occuring within botryoidal (decimeters in scale), banded 
deposits (up to a few m's thick, up to $\sim 15 \mathrm{~m}$ in diameter) of nearly pure siliceous sinter. Geyserite is thickest where closest to geysers or spring-vent sources, with some mound-like forms preserving hollow conduits. Furthermore, some fossil vent areas may be demarcated by silicified breccias. The locations of such conduits and hydrothermal breccias are mainly controlled regionally by positions of cross-cutting active faults, at least one of which usually comprises a major regional structure (e.g., Guido and Campbell, 2011; 2014; Drake et al., 2014; Watts-Henwood, 2015). At the micro-scale, very fine lamination with occasional micro-cross-lamination, bridges and cornices are important identifying features (Walter, 1976a), but commonly are obscured owing to diagenetic recrystallizaton. Phanerozoic sinters that may preserve geyserite occur within fluvial and lacustrine volcaniclastic deposits, and are associated with relatively quiescent, volcanic dome development during the late, postvolcanic stage in the evolution of a volcanic region (e.g., Rhynie/Windyfield cherts - Rice et al., 2002; Deseado Massif - Guido and Campbell, 2011). Sinters and geyserites are commonly affiliated with contemporaneously active faults that transported hydrothermal fluids, and may contain trace elements diagnostic of hydrothermal mineralization or alteration (e.g., Au, Ag, As, Sb, Hg, W, Mo; Rice and Trewin, 1988; Cuneen and Sillitoe, 1989; Guido et al., 2010). They typically are affiliated with a broad range of evidence for paleohydrothermal activity, such as epithermal mineral deposits, hydrothermal minerals, hydrothermal veins (e.g., quartz, barite), pervasive silicification of local geological materials, or inferred hydrothermal eruption breccias (Sillitoe, 1993; Trewin, 1993; McKenzie et al., 2001; Guido and Campbell, 2011, 2014; Hamilton, 2014).

\subsection{Geyserites as microstromatolites}


While the geyseritic lithofacies may be a robust indicator of high-temperature geothermal activity in terrestiral volcanic settings (section 4.1), microbial fossil associations in the pre-Quaternary geyserite record are extremely rare. As outlined in section 1.3, the early assumption of sterile conditions in the (near-)boiling waters of modern spring-vent areas was disproved by later microbiological and environmental studies. Strings and biofilms of hyperthermophilic bacteria and archaea are affiliated with geyser and vent discharges $(>75$ ${ }^{\circ} \mathrm{C}$ ), and are ubiquitously affixed to pool/channel floors and margins of proximal vents and discharge channels (e.g., Brock, 1967a; Cady and Farmer, 1996; Skirnisdottir et al., 2000; Blank et al., 2002; Cady, 2008). Recently developed techniques of fixation of biological materials and their molecular and ultrastructural characterization have contributed to a fuller portrayal of life at very high temperatures in present-day terrestrial hydrothermal environments (e.g., Cady et al., 1995; Cady and Farmer, 1996; Reysenbach and Cady, 2001, their fig. 5, p. 84). While Walter (1976a) found almost no microbial remains in bulk aciddigested geyserite residue from Yellowstone, Cady (2008) reported that acid-etching of intact geyserite, and a combination of high-resolution imaging, diffraction and spectroscopy enhanced the visibility of silicified cells (mainly filamentous bacteria) and silicified, microbial, extracellular polymeric substances (EPS).

The specific role of microorganisms in terms of their volumetric contribution to the build-up of the solid sinter deposit around spring-vents and geyser mounds, and to what degree they influence micro/macro-textures of geyserite, are still under discussion. Most reports acknowledge the dominant role of abiogenic processes - rapid cooling driving evaporation silica oversaturation - in the precipitation of non-crystalline opaline silica at geysers and vents (e.g., Göttlicher et al., 1998; Braunstein and Lowe, 2001; Lowe and Braunstein, 2003; McLoughlin et al., 2008). Synthetic stromatolites mimicking biogenic stromatolites in siliceous sinter have been grown in the absence of microbes (McLoughlin et 
al., 2008). Near-vent splash zones have been considered to be sites of sinter accumulation as “a consequence of physico-chemical processes alone" (McLoughlin et al., 2008, p. 102). Other experiments $\left(68^{\circ} \mathrm{C}\right.$, nearly neutral $\mathrm{pH}$, low sulfur concentrations; Lalonde et al., 2005) have shown that certain hot-spring thermophiles prevent cell silicification by producing an external EPS barrier upon which mineralization occurs, thereby metabolically enhancing silicification while at the same time decreasing the possibility of interior cellular material preservation at relatively high temperatures.

Nonetheless, many other studies have determined that microbes provide heterogeneous nucleation sites for the near-vent accumulation of silica (Jones et al., 1997a; Göttlicher et al., 1998; Jones and Renaut, 2003, 2004; Handley et al., 2005; 2008; Cady, 2008; Urusov et al., 2008). For example, Cady (2008) described development of "biological scaffolding" in actively forming Yellowstone geyserite, whereby initial colonization and early silicification of filamentous cells on subaerial surfaces delineated the base of each biogenic sinter lamina, while production of copious EPS and its silicification defined the upper surface of the lamina (Cady, 2008). In a spicular sinter rim bathed by the $75{ }^{\circ} \mathrm{C}$ waters of Champagne Pool, Wai-O-Tapu, New Zealand, Handley et al. (2008) showed that microbial activity is involved in the development of alternating laminae of both silicified filaments and homogeneous silica, the latter of which was determined experimentally to comprise silicified EPS. This study is a good example of cryptic biological templating within high-temperature microstromatolites that may be difficult to recognize in the geological record as biological in origin. Indeed, differential preservation of archaea cultured from marine hydrothermal vents indicates that EPS and some microbes can be silicified experimentally at high temperatures (Orange et al., 2009). In addition, Westall et al. (2000) established that EPS fossilizes more readily than microbes, and that fossil biofilms of EPS can be recognized in sedimentary paleoenvironments dating back to the Early Archean. Finally, because monomeric silica 
deposition produces a dense geyserite deposit, especially in nodular and cumulate/stratiform varieties, some geyserite may be relatively impermeable to subsequent post-depositional geological disturbances, thereby increasing its preservation potential. We have observed wellpreserved, solid blocks of Holocene geyserite (Fig. 1F) that have been caught up in landslide debris deposited atop corrosive, acidic fumaroles at the base of the neotectonically active Paeroa Fault at Te Kopia, Taupo Volcanic Zone, New Zealand. In summary, present-day and fossil geyserites may be considered biogenic microstromatolites, often confounded in their identification by taphonomic filtering which commonly destroys direct evidence of biological influence in their formation. In practice, uncovering definitive biosignatures in many geyserites may prove to be intractable, akin to issues encountered with Archean abiogenic "stromatolites" (see section 4.3).

It is clear from previous studies (e.g., Huber et al., 1998; Skirnisdottir et al., 2000; Jones and Renaut, 2003; Jones et al., 2003; Currie, 2005; Takacs-Vesbach et al., 2013), and consistent with the Patagonian results described herein, that microbes occur differentially in near-vent areas within environmentally specific (physical, geochemical) and spatially constrained micro-niches. Both low diversity and high diversity microbial communities are present in modern near-vent areas, and the dominant preserved (silicified) morphotypes are filamentous, although coccoids and rods also have been reported (e.g., Cady et al., 1995; Reysenbach and Cady, 2001; Blank et al., 2002; Jones and Renaut, 2003). As mentioned in section 1.3, Jones et al. (2003) highlighted the "enigma" of low-temperature microbes in a high-temperature geyser mound setting as being potentially problematic for interpreting the environmental settings of ancient sinters. However, the key issue is not whether geyserite represents a high-temperature lithofacies (section 2.2), but if the silicified microbes affiliated with the geyserite grew under the same extreme high-temperature conditions. Strongly fluctuating fluid temperatures (spatially and temporally) have been observed at active vent 
sites owing to the very nature of their dynamic discharge hydrodynamics (Braunstein and Lowe, 2001). Photosynthetic bacterial mats commonly encrust geyserite during extended periods of relative vent inactivity and lower discharge rates/temperatures (e.g. Fig. 1H versus Fig. 1I). Fayers and Trewin (2003, their fig. 4, p. 329) illustrated a good fossil example from the Devonian Windyfield chert. Thus, geyserite can be found in close spatial and stratigraphic association with lower temperature sinter facies (e.g., Fig. 1I, 1J). In modern settings, careful measurements at the microscale must be made in proximal vent areas to determine the actual temperatures under which the microbial communities are thriving today (e.g., Setchell, 1903; Brock, 1967a; Jones et al., 2003). While in the past it might have been a safety hazard to take accurate temperature measurements in dynamically boiling and splashing vent areas, use of remote infrared temperature measurement guns with laser sighting may allow safe, precise and instantaneous acquisition of vent-area temperatures (Currie, 2005). In a molecular characterization study of a small vent rimmed by geyserite at Sinter Waterfall, New Zealand, Currie (2005) reported laser-acquired geyserite surface temperatures of $48{ }^{\circ} \mathrm{C}$ for spicules and $46{ }^{\circ} \mathrm{C}$ for nodules owing to rapid cooling, despite the areas being splashed regularly by vent pool waters of $96{ }^{\circ} \mathrm{C}$. The abundant microbial communities on surfaces and preserved in the silica were diverse and dominated by cyanobacteria, with spicules hosting mainly filamentous Oscillatoriales, and nodules bearing coccoids (Synechococcus sp.), rods and other filaments (Currie, 2005).

With regard to the low-temperature biosignatures preserved in the geyser mound at Tokaanu reported by Jones et al. (2003), it was noted that cool micro-niches abound on the green- and orange-colored, cyanobacterial mat-covered sinter forming over an abandoned well-bore outflow area. Concrete blocks and logs were piled up over the HB-2 wellhead area, ostensibly to plug fluid upflow, and sinter has been forming in the outflow of the bore since ca. 1942. Temperatures range from up to $90{ }^{\circ} \mathrm{C}$ at the vent outlet to $\sim 30{ }^{\circ} \mathrm{C}$ at the mound base 
$\sim 1.5 \mathrm{~m}$ below (Jones et al., 2003). Significantly, no geyserite is forming on the mound, but rather siliceous stalactites and drapes (Jones et al., 2003). Hence, this modern, supposed "geyser mound" deposit illustrates well the unstable environmental conditions that can pervade spring-vent settings, as reflected in their spatially and temporally variable biological communities and sinter fabrics. Therefore, in places where fluid temperatures drop off dramatically over short distances from the vent, we would expect relatively low-temperature microbes to be preserved in close spatial association with siliceous sinter displaying geyseritic sedimentary textures. Moreover, other types of organic matter (e.g., leaf litter, wood) may occur in boiling spring-vent areas, having fallen or been washed into hot pools from surrounding vegetated areas (Channing and Edwards, 2013).

Stable carbon isotopes or lipid biomarkers potentially may provide environmentally distinctive biosignatures in siliceous sinter and geyserite. For example, carbon isotopes may enable delineation of high-temperature biofilm residue from photosynthetic bacterial mats of low-temperature apron pools and discharge channels, as shown in a study of isotopes and community genomics from biofilms in a decreasing temperature gradient at sinter-depositing Bison Pool, Yellowstone (Havig et al., 2011). Relatively enriched carbon isotopic values $\left(\delta^{13} \mathrm{C}-3.3\right.$ to $-12.8 \%$ ) were obtained from high-temperature biofilms collected in $71-93{ }^{\circ} \mathrm{C}$ spring-waters compared to the more isotopically depleted photosynthetic microbial mats sampled at moderate temperatures $\left(\delta^{13} \mathrm{C}-12.6\right.$ to $-19.6 \%$, at $\left.53-60{ }^{\circ} \mathrm{C}\right)$. At Bison Pool, modern sinter precipitate collected at $93{ }^{\circ} \mathrm{C}$ contained little carbon $(0.37 \pm 0.04 \% \mathrm{C}$ dry weight; likely owing to oxidation and hydrolysis; cf. Cady and Farmer, 1996), compared to biofilms and microbial mats ( 0.8 to $20 \% \mathrm{C}$ dry weight). In another study of high-temperature sinters $\left(75-80{ }^{\circ} \mathrm{C}\right)$ collected from alkali chloride and acid springs in New Zealand (Pancost et al., 2006), unusual microbial lipids with a range of carbon isotopic compositions $\left(\delta^{13} \mathrm{C}-40\right.$ to $+4 \%$ ), were distributed differentially among sites, and thus have potential as tools to study 
past life in paleo-hydrothermal settings. Detailed investigations of microbial communities and lipid biomarkers in pool-rim sinters at Champagne Pool $\left(75^{\circ} \mathrm{C}\right)$, New Zealand, also showed distinctive communities occupying different niches, as well as a decrease in venttemperatures over $~ 900$ years (Kaur et al., 2011; Gibson et al., 2014). In the Lower Geyser Basin at Yellowstone, intact polar lipids from archaeal streamer biofilms increase in abundance with increasing temperature; whereas, cyanobacterial signatures become dominant with decreasing temperature (e.g., Schubotz et al., 2013). Nonetheless, carbon can be redistributed during hydrothermal circulation or burial diagenesis, or stripped from sinter altogether over time. Hence, the applicability of these carbon fingerprinting techniques to sinters older than Quaternary age has yet to be demonstrated.

At the Jurassic Claudia sinter deposit in Patagonia, tubular microfabrics are present within the nodular geyserite lithofacies (Fig. 8E-G), and were studied in detail with laser Raman microscopy (Fig. 9). Based on morphology, spatial distribution and laser microRaman carbon-mapping, the tubular structures are interpreted to be biological in origin. The inferred filaments are clearly embedded within geyserite nodules; some portions show only faint filament molds. Nodular geyserite forms today in areas close to but not within boiling vent pools (e.g., Fig. 1D, 1E; Currie, 2005; Lynne, 2012), and thus represents a micro-niche within spring-vent areas of somewhat cooler overall temperatures in which microbes may flourish. The putative microbial inclusions in the Claudia nodular geyserite are extremely rare compared to the prokaryotic microfossils commonly found in the same paleo-geothermal field, the latter occuring in deposits inferred as moderate and low-temperature sinter aprons (Guido and Campbell, 2011, 2014). This disparate distribution across the Claudia hot-spring paleo-temperature gradient may be indicative of an overall taphonomic or diagenetic bias against biosignal preservation within the high-temperature geyserite lithofacies. The Claudia geyserite filaments could have been: (1) hyperthermophiles living under the extreme high 
temperatures of the spring-vent environment (cf. e.g., Brock, 1978; Skirnisdottir et al., 2000); (2) photosynthetic bacteria adapted to moderate temperature conditions, and tolerating occasional splashing by very high-temperature vent waters (cf. Currie, 2005); or (3) photosynthetic bacteria living in a cooler and later developed micro-niche, growing over the geyserite (cf. Fig. 1J) during diminished vent activity (cf. Fayers and Trewin, 2003). We prefer the second interpretation because the Claudia fossil microbes are entirely encased within nodular geyserite, rather than encrusting its outer surfaces.

\subsection{Geyserite, siliceous sinter and Precambrian cherts and stromatolites}

Beginning with the first descriptions of Precambrian microfossils, discovered in the Gunflint chert of Canada (Tyler and Barghoorn, 1954; Barghoorn and Tyler, 1965), biosignatures of early life on Earth have been compared to hot-spring sinter and geyserite with respect to their potential as environmental analogs, morphological similarity, and/or preservation in primary silica. For example, Tyler and Barghoorn (1954) reported fossils of "blue-green algae" and fungi from chert horizons in the Paleoproterozoic ( 1.88 Ga; Fralick et al., 2002) Gunflint Iron Formation of Ontario. They noted that "the quality and preservation of the plants and the lithologic appearance of the chert in thin section is quite comparable to that of the celebrated Rhynie chert deposit of the middle Devonian of Scotland" (Tyler and Barghoorn, 1954, p. 607). The "plants" to which some Gunflint fossils initially were referred were subsequently categorized as thermophilic, filamentous, photosynthetic flexibacteria like those found at Yellowstone (Brock, 1967a). Today the Rhynie chert is considered a gold-bearing hot-spring deposit of Lower Devonian age (400 Ma; Rice and Trewin, 1988; Rice et al., 2002). Barghoorn and Tyler (1965) further compared the gross morphology of columnar, finely laminated geyserite from Yellowstone to "pillar 
and thimble" stromatolitic structures of microfossil-rich Gunflint chert samples. The preservation style of siliceous sinters also has been related to other Precambrian deposits (e.g., Knoll and Simonson, 1981; Maliva et al., 2005).

Furthermore, silicified biotas dominate Proterozoic microfossil assemblages characterized by exceptional morphological preservation of biological structures (Lagerstätten) (e.g., Knoll, 1985; Knoll and Swett, 1985; Knoll and Butterfield, 1989; Butterfield et al., 1994), and silicified carbonaceous material also is an important archive for Archean biosignatures (e.g., Tice and Lowe, 2004; Westall et al., 2006; Westall, 2011; Westall et al., 2011). Early silicification of the organic matter was the key to this excellent preservation, although carbonaceous material often was partly degraded or transported prior to silicification (e.g., Knoll, 1985; Walsh and Lowe, 1999). Overall, a significant portion of our understanding of the anatomical detail, organism-environment interactions and evolutionary progress of early life derives from Precambrian carbonaceous material entombed in primary silica precipitates, of which Phanerozoic sinters may serve as useful analogs (Walter, 1972; Walter et al., 1972; Kohnhauser and Ferris, 1996; Trewin, 1996; Walter et al., 1996; Farmer, 2000; Kohnhauser et al., 2001; Guidry and Chafetz, 2003; Maliva et al., 2005). In comparison, sinters also entomb variably preserved organic matter, a taphonomic signal indicating shifts in timing of silicification in relation to life cycles and environmental conditions within the geothermal system (e.g., Fayers and Trewin, 2003; Channing and Edwards, 2009; Guido et al., 2010). Moreover, sinters have formed spectacular Lagerstätten (e.g., Trewin, 1993; 1996; Guido et al., 2010; García et al., 2011) that provide important, if environmentally restricted (sensu Knoll, 1985; Channing and Edwards, 2013) snapshots of terrestrial ecosystem content and functioning (e.g., Trewin and Rice, 2003, and references therein). Nonetheless, despite preservational and textural similarities, the physicochemical characteristics of geothermal systems are grossly different from the marine basins in 
which many Precambrian cherts formed (e.g., Planavsky et al., 2009), and hence comparisons will have limitations with respect to their broad applicability (Maliva et al., 2005).

Some Precambrian cherts contain abiogenic "stromatolites" that bear close resemblance to columnar geyserites with no visible microfossils (e.g., Walter, 1972; Pouba, 1978; Sommers and Awramik, 1996; Djokic et al., 2014). For example, Walter (1972) proposed a subaerial hydrothermal origin for certain geyserite-like morphotypes of laminated Si-Fe cherts from the Gunflint and Biwabik iron formations (Hofmann, 1969, type B and C stromatolites with "simple and distinct" laminae). He suggested use of the term "stiriolite" for abiogenic, siliceous chemical precipitates with geyserite-like textures mimicking stromatolites, and which occur in settings where a hydrothermal depositional environment cannot be established. Oehler (1972) and Krumbein (1983) proposed the term "stromatoloids" for stromatolite-like features lacking microfossils. Sommers and Awramik (1996) called for a detailed evaluation of the abiogenic "stromatolites" in the Proterozoic Gunflint Iron Formation, and presented statistical measurements of laminae thicknesses of Gunflint abiogenic "stromatolites" from Mink Mountain and compared them to microfossilrich stromatolites from the Schreiber locality. They discounted Walter's (1972) hypothesis that the Mink Mountain-style sedimentary structures could represent a fossil geyser deposit but conceded that "a spring deposit of some sort is possible." A subsequent detailed geochemical and petrographic study on a regional scale was undertaken for the two distinctive Gunflint siliceous stromatolite types - (1) microfossil-rich and (2) hematite-rich with distinct laminae and lacking microfossils (Planavsky et al., 2009). The latter are the abiogenic "stromatolites" that Walter (1972) compared to Yellowstone "abiogenic" geyserite. Microbial mediation was inferred in the formation of these hematite-rich, colloidal to dense laminae with low organic content, owing to their draping habit (similar in form to geyserite cornices), and thickening of laminae over peaks in convexity (Planavsky et al., 2009, their 
figs. 2 and 3, pp. 234-235). Iron isotopes and REE analyses enabled the two types of columnar biogenic stromatolites to be distinguished, one having formed in shallow water (microfossil-rich Schreiber Beach facies), and the other in somewhat deeper water (hematiterich Mink Mountain facies) and affiliated with Fe-oxidizing bacteria (not cyanobacteria) under low oxygen conditions. Field mapping indicated that the stromatolites can be traced over a distance of $>100 \mathrm{~km}$. Hence, they represent an extensive rather than localized (i.e., vent) ecosystem, and demarcate global expansion of iron-oxidizing bacterial communities at marine-shelf redox boundaries during the late Paleoproterozoic (Planavsky et al., 2009). Moreover, Recent micrometer-scale chemical and isotopic ( $\mathrm{O}$ and $\mathrm{Si}$ ) analyses also have shown that the Gunflint Iron Formation preserves some of the most pristine Precambrian cherts known, and suggest that seawater paleo-temperatures were about $45{ }^{\circ} \mathrm{C}$ (MarinCarbonne et al., 2012). Critically important in these new interpretations of Precambrian chert paleoenvironments and phylogenetic affinities of the preserved microbes (including laminated Fe-rich fabrics lacking filaments) was a combined field mapping, petrographic and geochemical approach that elucidated microbial metabolisms and physico-chemical conditions at the micron to regional scale.

In another example from Kokšín in Bohemia, Czech Republic, Pouba (1978) described Proterozoic, geyserite-like cherts that formed on the margin of the Barrandian Basin in an active volcanic arc. Pouba et al. (2000) examined REE patterns, oxygen isotopes and whole rock chemical analyses of carbonaceous stromatolitic chert breccias, and found them to be relatively enriched in trace metals $(\mathrm{K}, \mathrm{P}, \mathrm{V}, \mathrm{U}, \mathrm{Cr}, \mathrm{Sb})$. They concluded a volcanogenic influence with development in a shallow submarine or subaerial hydrothermal system. Finally, Djokic et al. (2014) are currently exploring the 3.49 Ga Dresser Formation, North Pole Dome, Pilbara craton, Western Australia, where they found geyserite-like textures proximal to putative stromatolites in siliceous sediments that also contain barite and pyrite, 
and have interpreted the proximal facies to represent a terrestrial paleo-hydrothermal system. All these examples illustrate that some laminated, columnar, siliceous, Precambrian sedimentary structures mimic geyserite textures and potentially represent the silicifying build-ups of microbial biofilms that left subtle to no morphological signatures of their presence. Several examples appear to preserve hydrothermal signatures, and all have required integrated field mapping, petrography, and micro-spatially targeted geochemical analysis in order to refine their character and inferred paleoenvironmental settings.

\section{Current issues and future research}

In this section, we briefly consider some current issues and suggest future research directions with respect to the study of geyserite and siliceous sinters that may have potential relevance for epithermal mineral exploration, for biosignature recognition in hightemperature terrestrial volcanic terrains, and for fingerprinting hydrothermal signatures in fossiliferous Precambrian cherts and in siliceous deposits on Mars. Firstly it has been estimated that $83 \%$ of all Phanerozoic epithermal deposits have been removed completely by erosion, with about 60,000 remaining to be discovered (Kesler and Wilkinson, 2009). The shallowest portions of epithermal systems may host siliceous sinters, which are even more susceptible to tectonic or volcanic disruption and erosion (Simmons et al., 1993; Gray et al., 1997). Despite this potential bias against the global preservation of geyserites, many more deposits must be exposed at the Earth's surface than are presently known or recognized (Fig. 2). With respect to economic mineral prospecting, geyserites and affiliated silicified hydrothermal breccias signal vent locations (i.e., hydrothermal upflow zones) and may contain elevated trace metal contents (e.g., McKenzie et al., 2001; Zhou et al., 2013) that point to precious metal mineralization at depth (e.g., Rice and Trewin, 1988; Guido et al., 
2010; Hamilton, 2014). Even if barren, sinter deposit size and facies associations can indicate relative longevity and/or volume of fluid flow through the shallow crust, possibly hinting at the potential of subsurface mineralization (e.g., Guido and Campbell, 2014). While sinters are generally mapped during epithermal mineral exploration, they rarely are studied for their paleo-hydrologic or paleoenvironmental signals by economic geologists. We also have found that silicified sediments and silicified travertines are commonly misidentified as sinters. Thus, clear criteria are needed for recognition and characterization of sinters versus pseudosinters for use in resource exploration (e.g., Guido and Campbell, 2011; in preparation). Silica residue, formed by sulfuric acid-alteration of volcanic rocks, also may be mistaken for sinter, with the former typified by thin ( $\leq 1 \mathrm{~cm}$ thick) deposits exhibiting corrosion features and affiliated with native sulfur and mineral efflorescences in Holocene examples (Rodgers et al., 2004). In addition, attempts should be made to increase the number of known sinter and geyserite occurrences in the geological record. Channing and Edwards (2013) made a concerted effort to locate Phanerozoic sinter deposits in a study of paleobotanical content within low-temperature facies, but many of the mentioned deposits have not yet been confirmed as sinters. Whether they preserve geyserite is also largely unknown, and the possibility of discovering Precambrian sinters was not explored. With facies models now well-established for modern and scattered Phanerozoic sinters (e.g., Cady and Farmer, 1996; Jones et al., 1998; Guidry and Chafetz, 2003; Guido and Campbell, 2011; Lynne, 2012), more deposits have the potential to be recognized, and their economic, evolutionary and paleoenvironmental utility more fully realized.

In the search for the extreme temperature limits of life on Earth, past and present, and given that vent areas of geothermal settings deposit minerals upon the most heat-loving biota known to exist on land, more geyserite deposits should be located and studied with a combined petrographic and geochemical approach. However, owing to the common 
occurrence of cooler-facies microbes overprinting spicular, columnar and nodular geyserite in the rapidly fluctuating temperature conditions within splash and spray zones (e.g., Fig. 1J), a more promising target in looking for the world's "hottest" fossilized life on land could be in the earthy, particulate, stratiform geyserite that develops fully submerged in boiling pools and proximal discharge channels (e.g., Fig. 1G; Walter, 1976a; Lowe et al., 2001; Braunstein and Lowe, 2003; Lowe and Braunstein, 2003). This geyserite variety, by its nature, is subject to more uniform, very high temperature conditions during accumulation. Nonetheless, the challenge here is that finely laminated vent-pool deposits accumulate relatively slowly and therefore organic matter can be rapidly decomposed and oxidized in the very high temperatures of the pools, or be transported out of the depositional environment by vigorous boiling and effusive discharge. In addition, these pool-floor sediments are not well studied, rarely recognized in geological deposits (e.g., Watts-Henwood, 2015), and easily could be mistaken for lower-temperature derived, thinly laminated sinter, especially if it has undergone diagenetic modification to "massive mottled, diffusely layered" quartz (Walter et al., 1996). We have found this mottled diagenetic fabric to be very common in fossil sinter deposits, especially in distal, low-temperature sinter-apron lithofacies containing porous palisade microbial textures susceptible to patchy quartzose replacement (Campbell et al., 2001). A case where such misidentification may have occurred is in a study of Quaternary sinter from Artist Point, Yellowstone. Hinman and Walter (2005, their fig. 5C-D, p. 206) illustrated volumetrically abundant, "stratiform geyserite," which may alternatively represent a low-temperature palisade texture that has been diagenetically altered to "massive mottled, diffusely layered" quartz (sensu Walter et al., 1996, cf. their fig. 14B, p. 510). Geyserite is, by definition, restricted to vent areas of boiling springs and geysers, and therefore is not expected to be volumetrically abundant in any given paleo-geothermal field. 
Another issue to tackle in future research would be to continue to refine methods for recognizing biosignatures in high-temperature hot-spring lithofacies. Handley et al.'s (2005; 2008) field and experimental studies on the formation of spicular sinter around the rim of the $75^{\circ} \mathrm{C}$, gold-bearing Champagne Pool, New Zealand, show that apparently abiogenic features - dense, homogeneous siliceous laminae - could in fact be biogenic, and specifically represent silicified EPS. The implications are that relatively nondescript sedimentary features in Precambrian or other rocks also could turn out to be mineralized biofilms (e.g., Westall et al., 2000; 2006). Thus, studies such as these open up the possibility that far greater volumes of "abiogenic" siliceous deposits may, in fact, represent metabolically enhanced silicification and/or silica templating on biofilms. Hence, more detailed field and laboratory experiments on microbe-mineral interactions affiliated with modern geyserites (e.g., Cady, 2008), similar to those conducted on microstromatolites grown on glass slides in New Zealand (Mountain et al., 2003; Handley et al., 2005; 2008) and Iceland (Tobler et al., 2008), may reveal the nature, taphonomy and preservation of biosignatures within the fine laminae of geyserites.

A further outstanding problem is the need to establish clear criteria for differentiating silica sources in Precambrian cherts, which are a significant archive of early fossilized life, and contain geochemical and other clues for the conditions under which it developed. The topic is too large to review in detail here, but a few key issues are outlined, including the relevance of hydrothermal precipitates from terrestrial hot springs as fluid-source analogs for some Precambrian cherts, and the potential pathways of silica diagenesis affecting fossil and environmental signal preservation. As background, some of the best-preserved Precambrian microfossils and biofilms appear to have been entombed by silica in a manner akin to wood petrification (Knoll, 1985, and references therein; Westall et al., 2006, 2011). Maliva et al. (2005) also noted that Proterozoic cherts with good biosignature preservation predominantly formed in peritidal settings, and they established petrographic criteria for differentiating 
carbonate- and evaporite-replacement cherts from those having developed by primary silica precipitation. Enhanced seawater evaporation on shallow peritidal platforms in warmer oceans than today, combined with the absence of Phanerozoic-style biomineralization as a silica sink, facilitated direct silica precipitation from Precambian seawater (Siever, 1992; Maliva et al., 2005). Additional suggested sources of primary Precambrian silica include hydrothermal inputs and weathering of volcanic materials (Maliva et al., 2005; MarinCarbonne et al., 2012).

Several studies have reported textural and compositional evidence for a hydrothermal origin of some Precambrian cherts. For example, Maliva et al. (2005) illustrated similarities in quartz textures between some Proterozoic cherts precipitated from primary silica and those of quartzose hot-spring sinters. Sugitani (1992) outlined features of hydrothermal Precambrian chert in the Pilbara, Australia, including depletion in detrital materials, low $\mathrm{MnO} / \mathrm{Fe}_{2} \mathrm{O}_{3}$ values, low concentration of heavy metals, positive Eu anomalies, and low $\mathrm{Co} / \mathrm{Zn}$ and $\mathrm{Ni} / \mathrm{Zn}$ values. Other studies downplay the significance of hydrothermal sources of silica in Precambrian cherts, and have utilized Ge/Si ratios, and micrometer-scale elemental and oxygen and silicon isotopic criteria to infer the importance of silica derived from seawater or continental weathering (e.g., Hamade et al., 2003; Marin-Carbonne et al., 2012). Additional detailed studies of Archean ( $3.5 \mathrm{Ga})$ sedimentary cherts and chert dikes have utilized silicon isotopes and trace elements to fingerprint secondary cherts replacing precursor materials (e.g., volcaniclastic inputs; S-type cherts) from primary hydrothermal and seawater precipitated (C-type) cherts (van den Boorn et al., 2007; 2010). These fine-scale identifications of chert types have allowed new estimations of paleo-temperatures for Archean seawater $\left(\sim 55^{\circ} \mathrm{C}\right)$ and Proterozoic seawater $\left(\sim 45^{\circ} \mathrm{C}\right)$ from diagenetically wellcharacterized micro-samples (van den Boorn et al., 2007; 2010; Marin-Carbonne et al., 2012; 2014), a significant decrease from earlier reports of up to $70{ }^{\circ} \mathrm{C}$ for Precambrian seawater 
(Knauth and Lowe, 2003). In these estimations, modern seafloor and land-based hydrothermal deposits served as important end-member silicon reservoirs with which to compare and constrain the origin of the varying Si-isotopic signatures obtained from the Precambrian cherts (e.g., van den Boorn et al., 2007). Additional studies are warranted of the petrography, isotopes and elemental composition of silica from relevant Phanerozoic analogues and Precambrian cherts, while monitoring biosignature preservation of Si-enclosed microbial fossils along diagenetic and metamorphic gradients (cf. Winter and Knauth, 1992; Orange et al., 2009), in order to extract primary biological and environmental signatures of early Earth habitats and inhabitants.

Finally, with respect to the search for habitability of extra-terrestrial locations, the Home Plate silica deposit in Gusev Crater on Mars (Squyres et al., 2008) has been interpreted as potentially representing a near-neutral $\mathrm{pH}$, alkali chloride hot-spring deposit (Ruff et al., 2011). Outcrop features of the hydrothermal silica include platy bedding and wind-sculpted, nodular/knobby digitate protrusions, containing massive, brecciated and porous sponge-like fabrics (Ruff et al., 2011; their figs. 23, 24, 43d). Neither finely laminated textures nor ventlike geomorphologies are evident in the siliceous deposits studied at Home Plate. We suggest that for putative Martian hot spring analog studies, one focus could be on sinters accumulating in acid-sulfate-chloride springs (e.g., compare to Schinteie et al., 2007; their figs. 5, 8, 9), which may represent a closer match to Martian surface chemistry conditions (e.g., Farmer, 2000; Benison and Laclair, 2002; Kerr, 2004; Bullock, 2005; McCollom and Hynek, 2005).

\section{Conclusions}


The lithofacies features of vent-restricted siliceous hot-spring deposits, or geyserite, constitute localized, dense, botryoidal, fine laminations of nearly pure silica that develop distinctive macro-morphologies and microtextures controlled largely by spring-vent hydrodynamics and distance from the emission point. These stromatolite-like features include stratiform to cumulate geyserite forming in subaqueous pools and within proximal discharge channels; spicular geyserite developing from splash events; and (pseudo)columnar, nodular, bulbous, and beaded varieties accumulating in subaerial, near-vent areas intermittently bathed by hot-water surge and overflow. Such lithofacies associations are robust field identifiers of modern and ancient high-temperature vents and fissures, and are preserved in sinters as old as Devonian (400 Ma). Nonetheless, reported geyserite occurrences are still rare on a global scale, and many supposed sinters are, in fact, silicified volcaniclastic sediments or silicified travertine.

Microbes flourish in the hot $\left(>75^{\circ} \mathrm{C}\right)$ spring-vent and geyser mound discharges of present-day geothermal fields, and therefore represent the highest temperature life forms on land. Some are obligate hyperthermophiles while others, including cyanobacteria, tolerate intermittent splashing by scalding waters. Despite mineralization by silica, the particular taphonomic characteristics of very high temperature habitats generally do not foster the longterm preservation of these microorganisms. Therefore, while geyserite may be considered a type of biogenic microstromatolite, only some modern and an extremely low number of ancient examples yield recognizable microbial remains. Hence, geyserite commonly appears abiogenic owing to silica infill and the apparently poor preservation potential of the cellular material of near-vent microbial biofilms compared to the readily silicified, filamentous photosynthetic bacteria with thick sheaths that dominate the chromatically vivid, copious microbial mats found on cooler sinter-apron terraces. Both stable carbon isotopes and lipid biomarkers hold promise as possible biosignatures but have yet to be extracted from pre- 
Holocene geyserites. Owing to their microbial content, formation by direct silica precipitation, and hydrothermal setting, sinters in general and geyserite in particular have been compared to some Precambrian cherts. Definitive in situ geyserite deposits of the preQuaternary geological record, such as those found in the remarkably well-preserved, Jurassic, Yellowstone-style geothermal landscapes of Patagonia, provide context for a better understanding of the signatures of hydrothermal systems, and the mechanisms of preservation and diagenesis of high-temperature-adapted microorganisms, which may aid early life studies and the exploration for precious metals deposits and habitable settings on Mars.

\section{Acknowledgements}

For financial and other support we gratefully acknowledge the National Geographic Society, INREMI, the RSNZ Marsden and Charles Fleming Senior Scientist funds, and the University of Auckland's Faculty Research Development Fund. Mirasol Resources supplied locality information for the Claudia deposits, and the Mauricio Hochschild mining company granted access permission for field work on the mining property. Jack Farmer (Arizona State University) and Nancy Hinman (University of Montana) assisted with logistical and other support at Yellowstone. Jiř́ Zachariáš (Charles University) and Petra Janku (Auckland) kindly provided access to and translation of the Czech literature. Fruitful discussions, locality data and literature references were provided by Pat Browne (University of Auckland), Alan Channing (Cardiff University), Bryan Drake (University of Auckland), Rina Herdianita (Bandung Institute of Technology), Kim Handley (University of Chicago), Nancy Hinman, Robin Renaut (University of Saskatchewan), Lynn Rothschild (NASA Ames Research Center), Noel White (University of Queensland) and Colin Wilson (Victoria University). This study was completed during a research fellowship to KAC with LE STUDIUM®, Loire Valley Institute for Advanced Studies, région Centre, and the Exobiology Research Group, 
Centre de Biophysique Moléculaire, Centre National de la Recherche Scientifique (CNRS), Orléans, France. Constructive reviews from Jake Lowenstern (U.S.G.S.) and Robin Renaut improved the quality of the manuscript.

\section{Glossary}

Apron terrace: in this usage signifies step-like terraces (m's to 10's of m's thick and up to $\sim 1 \mathrm{~km}$ in diameter) of travertine or sinter building upward and outward from geyser or spring-vent sources via carbonate or silica precipitation from discharging geothermal waters, e.g. Mammoth travertine terraces or Fountain Paint Pots sinter apron affiliated with the Clepsydra/Fountain/Red geyser group in the Lower Geyser Basin, Yellowstone National Park, Wyoming, U.S.A. [Walter, 1976b; Cady and Farmer, 1996; Farmer, 2000].

Acid-sulfate-chloride geothermal fluid: hot waters with $\mathrm{pH}$ as low as 0 (but typically 2-5) that originate through subsurface mixing of sulfate and chloride waters, oxidation of $\mathrm{H}_{2} \mathrm{~S}$ in chloride waters, near-surface condensation of volcanic gases in meteoric waters, or dissolution of sulfate-bearing bedrock via migrating chloride waters; thin sinter precipitates as well as kaolinite, jarosite, sulfur and gypsum, in locations such as the northern Waiotapu and the Rotokawa geothermal fields, New Zealand [Ellis and Wilson, 1961; Renaut and Jones, 2011].

Alkali chloride geothermal fluid: derived from hot, saline and chloride-rich fluids (typically $500-15,000 \mathrm{mg} / \mathrm{kg}$, up to $\sim 400{ }^{\circ} \mathrm{C}$ at reservoir depths of $\sim 3 \mathrm{~km}$ ) of nearly neutral $\mathrm{pH}$, derived largely from circulating meteoric waters that have reacted with host rocks (becoming silica-rich, >300 ppm Si), and where discharged at the Earth's surface as hot springs they commonly overlie permeable zones of major thermal fluid upflow [Henley and Ellis, 1983; Renaut and Jones, 2011].

Archaea: single-celled or filamentous prokaryotes (0.5-2 $\mu \mathrm{m}$ diameter) constituting a major phylogenetic domain of life; they reveal the absence of a cell nucleus, internal 
membranes and organelles, and are characterized by unique genetic machinery, cell wall composition, and membrane lipids; many are extremophiles and all are chemotrophic [Thiel, 2011a].

Bacteria: single-celled prokaryotes comprising a major phylogenetic domain of life, most with cell envelopes of two double-layer membranes; bacteria are taxonomically and metabolically more diverse than archaea [Hoppert, 2011].

Biofilms: very thin organic coatings on surfaces, constituting microbial cells enclosed in extracellular polymeric substances (EPS) [Reitner, 2011].

Biosignatures: are found in minerals, sediments and rocks; they encompass the morphological, chemical and/or isotopic traces of organisms and their metabolic activities and products [Westall and Cavalazzi, 2011].

Chalcedony: a cryptocrystalline variety of quartz that may be radial fibrous in texture; it constitutes much chert, often formed aqueously to fill or line cavities [Jackson et al., 2007].

Chemolithotrophic: generation of energy for cell biosynthesis and maintenance from oxidation of inorganic compounds in the absence of light; e.g. archaea perform inorganic carbon fixation using hydrogen gas derived from geochemical processes or from microbial metabolism [Thiel, 2011a, b].

Cyanobacteria: a large and morphologically diverse group of photoautotrophic prokaryotes (gram-negative bacteria), many filamentous or coccoidal, that perform oxygenic photosynthesis; they have light-harvesting pigments, a durable mucilaginous sheath embedded in EPS, and broad environmental tolerances, including extreme and fluctuating conditions [Palinska et al., 2006; Hoppert, 2011; Mohr et al., 2011].

Diagenesis [mineral]: the chemical and physical changes in minerals during and after their initial formation, involving addition and removal of material; transformation by 
dissolution, recrystallization, and replacement; and/or phase changes (e.g., silica phase mineral transitions from non-crystalline opal-A, to paracrystalline opal-CT and opal-C, to microcrystalline quartz) [Jackson et al., 2007; Rodgers et al., 2004].

Diagenesis [sedimentary]: the chemical, physical and biological changes undergone by a sedimentary deposit after its initial deposition, during and after lithification, and exclusive of weathering and metamorphism; includes processes such as compaction, cementation, reworking, authigenesis, replacement, crystallization, leaching, hydration, bacterial action, and occurring at up to $1 \mathrm{~kb}$ pressure and $100-300{ }^{\circ} \mathrm{C}$ within the shallow crust [Jackson et al., 2007].

Epithermal deposits: hydrothermal precious metal (e.g., Au, Ag) deposits that formed within $\sim 1.5 \mathrm{~km}$ depths of the Earth's surface at $50-200{ }^{\circ} \mathrm{C}$ and hosted mainly by volcanic rocks within hydrothermal systems that commonly include surface sinters; lowsulfidation, or adularia-sericite epithermal deposit types, develop from near-neutral, sulfidepoor, reduced fluids [Sillitoe, 1993].

EPS: extracellular polymeric substances, or hydrated mucus substances secreted by biofilms and microbial mats attached to surfaces [Reitner, 2011]; EPS enables cells to be adaptable and resilient, important for ecosystem functioning and microbe-mineral interactions [Decho, 2011].

Facies [sedimentary]: the characteristics of a sedimentary deposit reflecting a certain environment or mode of origin [Jackson et al., 2007].

Facies assemblage: in this usage refers to groups of sinter or travertine textures representing a temperature gradient $\left(\sim 100-25^{\circ} \mathrm{C}\right)$ in vent to marsh environments at proximal, middle or distal apron terrace positions within a geothermal system.

Flexibacteria: a term used to describe gliding bacteria such as the photosynthetic flexibacterium, Chloroflexus [Soriano, 1973]. 
Geothermal: pertaining to heat of the interior of the Earth; evaluation of geothermal fluids in this study is restricted to those from which the surface emission of steam or hot waters is largely of meteoric origin, and where magmatic heat at depths up to $8 \mathrm{~km}$ drives convection of groundwater via faults, fractures and permeable horizons in the upper crust [Henley and Ellis, 1983; Renaut and Jones, 2011].

Geyser: A type of hot spring that intermittently erupts turbulent jets and surges of hot water and steam at (near)boiling conditions [Jones and Renaut, 2011].

Geyserite: a dense, banded or laminated variety of siliceous sinter (opal) occurring at and near the vents of geysers, spouters and some high-temperature springs [Renaut and Jones, 2011].

Heterotroph: a microorganism that obtains carbon from an organic carbon source, e.g. use of metabolic products of other microbes formed during organic matter degradation [Thiel, 2011b].

Hot spring: a discharge of heated $\left(>35^{\circ} \mathrm{C}\right)$, typically meteoric water from a vent or fissure at the Earth's surface [Jones and Renaut, 2011].

Hydrothermal alteration: a general term encompassing the mineralogical, textural and chemical responses of rocks to a changing thermal and chemical environment in the presence of hot water, steam or gas; in geothermal fields occurring at relatively high waterrock volume ratios via mineral phase transformation, growth of new minerals, mineral dissolution and precipitation, and ion exchange reactions [Henley and Ellis, 1983].

Hydrothermal eruption: the rapid, shallow subsurface formation of steam due to a sudden pressure reduction in a geothermal reservoir, causing flashing, boiling and rock brecciation [Browne and Lawless, 2001].

Hydrothermal eruption breccias: Deposits from hydrothermal eruptions, which are typically very poorly sorted, matrix-supported, and may contain hydrothermally altered clasts 
derived from within the geothermal reservoir, with lithologies and alteration mineralogies indicative of subsurface conditions [Browne and Lawless, 2001].

Hyperthermophilic: extreme heat-loving archaea and bacteria isolated from geothermal and hydrothermal environments, with optimal growth temperature range of 80$110{ }^{\circ} \mathrm{C}$ [Stetter, 1996].

Lagerstätten: sedimentary deposits yielding extraordinary fossils of exceptional preservation.

Low-sulfidation: see entry for epithermal deposits

Macrotexture: as used herein, a sedimentary rock texture visible to the naked eye, or observed in hand sample with a hand lens or binocular microscope.

Massive sulfide deposit: a mass of unusually abundant sulfide minerals (>60\%), e.g. deposits forming around deep-sea, mid-ocean ridge hydrothermal vents [Flores and Reysenbach, 2011].

Mesocrystalline: a term applied to quartz with typical microcrystalline textures but exhibiting a larger crystal size of $20 \mu \mathrm{m}$ or greater; typical of Phanerozoic sinter microfabrics [Maliva et al., 2005].

Mesophilic: microbes with optimal growth temperatures of approximately $20-45^{\circ} \mathrm{C}$ [Prescott et al., 2002].

Microcrystalline: as used herein in reference to quartz, with a crystal size of $<20 \mu \mathrm{m}$ and individual crystal textures characterized by irregular, crenulate to diffuse crystal boundaries and an undulose (sweeping) extinction pattern [Maliva et al., 2005].

Microtexture: as used herein, the microscopic-scale texture of a sedimentary rock or mineral.

Paracrystalline: referring herein to opal-CT and opal-C, silica phase minerals in sinter and silica residue undergoing mineral diagenesis; comprising structurally ordered 
domains of cristobalite \pm tridymite within a disordered opal matrix, and displaying X-ray powder diffraction patterns of broad or narrow bands, respectively, about a $\sim 4 \AA$ peak [crystallinity and silica phase minerals detailed further in Rodgers et al., 2004].

Polysaccharide: a carbohydrate comprising sugar molecules bonded together.

Silica residue: thin $(<\sim 10 \mathrm{~cm})$, irregular siliceous veneers of opal-A found at the Earth's surface in acidic geothermal areas, formed from reactions between silicate country rock and steam condensate acidified by sulfuric acid that is derived from oxidation of $\mathrm{H}_{2} \mathrm{~S}$ [Rodgers et al., 2004].

Sinter: a typically white to gray sedimentary rock chiefly composed of silica that precipitates as non-crystalline opal-A $\left(\mathrm{SiO}_{2} \cdot n \mathrm{H}_{2} \mathrm{O}\right)$ from (near)boiling waters $\left(\sim 100-75^{\circ} \mathrm{C}\right)$ in the vent areas of springs and geysers, and from the cooling waters $\left(<75^{\circ} \mathrm{C}\right.$ to ambient $)$ flowing over their adjacent discharge aprons [Renaut and Jones, 2011]. It commonly accumulates in mounds and terraces, may form from acidic (deposits cms to 10's of cms thick) or alkaline (deposits up to 10's of meters thick) hot springs saturated in silica, and becomes more crystalline during silica phase mineral diagenesis to opal-CT, opal-C and quartz (see diagenesis [mineral]).

Spouter: a hot spring exhibiting continuous eruptive activity at the vent source [Jones and Renaut, 2011].

Taphonomy: used in paleoecological and paleontological analysis to encompass the sum total of what could happen to an organism after death and before permanent burial and diagenesis, and may include post-mortem disarticulation owing to scavenging, bacterial decay, burial/exhumation cycles, or breakage/transport of hard parts (bones, teeth, shells).

Travertine: as used here, precipitated calcium carbonate (predominantly calcite and aragonite) from spring-fed, heated waters [Jackson et al., 2007; see Pentecost (2005) for indepth description of thermogene travertines]. 


\section{References}

Allen, E.T., 1934. The agency of algae in the deposition of travertine and silica from thermal waters. American Journal of Science 28, 373-389.

AngloGold Ashanti, 2012. Mineral Resource and Ore Reserve Report. (182 pp. http://www.aga-reports.com/12/).

Barghoorn, E.S., Tyler, S.A., 1965. Microorganisms from the Gunflint Chert. Science 147, $563-577$.

Barion S., Franchi M., Gallori E., Di Giulio M., 2007. The first lines of divergence in the Bacteria domain were the hyperthermophilic organisms, the Thermotogales and the Aquificales, and not the mesophilic Planctomycetales. BioSystems 87, 131910.1016/j.biosystems.2006.02.011.

Benison, K.C., Laclair, D.E., 2002. Acid sedimentary environments on Mars? Possible terrestrial analogs. Geological Society of America, abstracts with program, annual meeting, 34(6), 174.

Blank, C.E., Cady, S.L., Pace, N.R., 2002. Microbial composition of near-boiling silicadepositing thermal springs throughout Yellowstone National Park. Applied and Environmental Microbiology 68, 5123-5135.

Bock, G.R., Goode, G.A. (Eds.), Evolution of Hydrothermal Ecosystems on Earth (and Mars?): Proceedings of the Ciba Foundation Symposium, 202, J. Wiley, Chichester, 334 pp.

Bott, T.L., Brock, T.D., 1969. Bacterial growth rates above $99^{\circ} \mathrm{C}$ in Yellowstone hot springs. Science 164, 1411-1412. 
Boudreau, A.E., Lynne, B.Y., 2012. The growth of siliceous sinter deposits around hightemperature eruptive hot springs. Journal of Volcanology and Geothermal Research 247$248,1-8$.

Boussau, B., Blanquart, S., Necsulea, A., Lartillot, N., Gouy, M., 2008. Parallel adaptations to high temperatures in the Archaean eon. Nature 456, 942-945.

Braunstein, D., Lowe, D.R., 2001. Relationship between spring and geyser activity and the deposition and morphology of high temperature $\left(>73^{\circ} \mathrm{C}\right)$ siliceous sinter, Yellowstone National Park, Wyoming, U.S.A. Journal of Sedimentary Research 71, 747-763.

Brock, T.D., 1967a. Life at high temperatures. Science 158, 1012-1019.

Brock, T.D., 1967b. Micro-organisms adapted to high temperatures. Nature 214, 882-885.

Brock, T.D., 1978. Thermophilic Microorganisms and Life at High Temperatures. SpringerVerlag, New York, 465 p.

Brock, T.D., Brock, M.L., 1966. Temperature optima for algal development in Yellowstone and Iceland hot springs. Nature 209, 733-734.

Brock, T.D., Brock, M.L., 1971. Temperature optimum of non-sulfur bacteria from springs at $90{ }^{\circ} \mathrm{C}$. Nature $233,494-495$.

Brock, T.D., Brock, M.L., Bott, T.L., Edwards, M.R., 1971. Microbial life at $90{ }^{\circ}$ C: the sulfur bacteria of Boulder Spring. Journal of Bacteriology 107, 303-314.

Browne, P.R.L., Lawless, J.V., 2001. Characteristics of hydrothermal eruptions, with examples from New Zealand and elsewhere. Earth-Science Reviews 52, 299-331.

Bullock, M.A., 2005. The flow and ebb of water. Nature 438, 1087-1088.

Butterfield, N.J., Knoll, A.H., Swett, K., 1994. Paleobiology of the Neoproterozoic Svanbergfjellet Formation, Spitsbergen. Fossils \& Strata no. 34, 88 p.

Cady, S.L., 2008. Hyperthermophilic biofilm mineralization; implications for biosignature detection. Geological Society of America, Abstracts with Programs 40(6), 295-296. 
Cady, S.L., Farmer, J.D., 1996. Fossilization processes in siliceous thermal springs: trends in preservation along thermal gradients. In: Bock, G.R., Goode, G.A. (Eds.), 150-173.

Cady, S.L., Farmer, J.D., Des Marais, D.J., Blake, D.F., 1995. Columnar and spicular geyserites from Yellowstone National Park, WY: scanning and transmission electron microscopy evidence for biogenicity. Geological Society of America, Abstracts with Programs 27, A305.

Cady, S.L., Farmer, J.D., Grotzinger, J.P., Schopf, J.W., Steele, A., 2003. Morphological biosignatures and the search for life on Mars. Astrobiology 3, 351-368.

Campbell, K.A., Buddle, T.F., Browne, P.R.L., 2003. Late Pleistocene siliceous sinter associated with fluvial, lacustrine, volcaniclastic and landslide deposits at Tahunaatara, Taupo Volcanic Zone, New Zealand. Transactions of the Royal Society of Edinburgh (Earth Sciences) 94, 485-501.

Campbell, K.A., Sannazzaro, K., Rodgers, K.A., Herdianita, N.R., Browne, P.R.L., 2001. Sedimentary facies and mineralogy of the Late Pleistocene Umukuri silica sinter, Taupo Volcanic Zone, New Zealand. Journal of Sedimentary Research 71, 727-746.

Capece, M.C., Clark, E., Saleh, J.K., Halford, D., Heinl, N., Hoskins, S., Rothschild, L.J., 2013. Polyextremophiles and the constraints for terrestrial habitability. J. Seckbach et al. (eds.), Polyextremophiles: Life Under Multiple Forms of Stress. Cellular Origin, Life in Extreme Habitats and Astrobiology 27, 3-59, DOI 10.1007/978-94-007-6488-0_1.

Channing, A., Edwards, D., 2009. Silicification of higher plants in geothermally influenced wetlands: Yellowstone as a Lower Devonian Rhynie analog. Palaios 24, 505-521.

Channing, A., Edwards, D., 2013. Wetland megabias: ecological and ecophysiological filtering dominates the fossil record of hot spring floras. Palaeontology 56, 523-556.

Corbett, G.J., 2002, Epithermal gold for explorationists: AIG Presidents Lecture, AIG On Line Journal, April 2002, AIG website, www.aig.asn.au. 
Cuneen, R., Sillitoe, R.H., 1989. Paleozoic hot spring sinter in the Drummond Basin, Queensland, Australia. Economic Geology 84, 135-142.

Currie, A.E., 2005. Prokaryotic communities of geyserite deposits surrounding a high temperature alkali chloride hot spring. Unpublished MSc Thesis, The University of Auckland, $133 \mathrm{p}$.

Darling, W.B., Spiro, B., 2007. Oxygen isotopes in hydrothermal sinters as an indicator of Quaternary lakewater composition in the Kenya Rift Valley. Proceedings of the 2012 International Conference on Water-Rock Interactions, Kunming, China, 31 July-5 August, 2007, Taylor \& Francis Group, London, 1475-1479.

Davis, B.M., 1897. The vegetation of the hot springs of Yellowstone Park. Science 6, 145157.

Decho, A.W., 2011. Extracellular polymeric substances (EPS). In: J. Reitner and V. Thiel (Editors), Encyclopedia of Geobiology. Springer, pp. 359-361

Djokic, T., Van Kranendonk, M.J., Walter, M.R., 2014. Some liked it hot: metabolic pathways in the c. 3.5 Ga Dresser Formation, North Pole Dome, Pilbara Craton, Western Australia. Conference on Biosignatures across space and time, Nordic Network of Astrobiology \& Centre for Astrobiology, Bergen, May 2014, p. 110.

Drake, B.D., Campbell, K.A., Rowland, J.V., Guido, D.M., Browne, P.R.L., Rae, A., 2014. Evolution of a dynamic paleo-hydrothermal system at Mangatete, Taupo Volcanic Zone, New Zealand. Journal of Volcanology and Geothermal Research 282, 19-35.

Ellis, A.J., Wilson, S.H., 1961. Hot spring areas with acid-sulphate-chloride waters. Nature $191,696-698$.

Ertel, B.J., 2009. Lithofacies and Microfacies of a Fossil Hot Spring System, McGinness Hills, Nevada. Unpublished M.S. Thesis, University of Montana, Missoula, 51 p. 
Farmer, J.D., 2000. Hydrothermal systems: Doorways to early biosphere evolution. GSA Today 10, 1-9.

Farmer, J.D., Des Marais, D.J., 1999. Exploring for a record of ancient martian life. Journal of Geophysical Research Planets 104 (E11), 26977-26995.

Fayers, S.R., Trewin, N.H., 2003. A review of the palaeoenvironments and biota of the Windyfield chert. Transactions of the Royal Society of Edinburgh: Earth Sciences 94, 325-339, 125-147.

Féraud, G., Alric, B., Fornari, M., Bertrand, H., Haller, M., 1999. ${ }^{40}$ Ar/-Ar dating of the Jurassic volcanic province of Patagonia: migrating magmatism related to Gondwana break-up and subduction. Earth and Planetary Science Letters 172, 83-96.

Fernandez-Turiel, J.L., Garcia-Valles, M., Gimeno-Torrente, D., Saavedra-Alonso, J., Martinez-Manent, S., 2005. The hot spring and geyser sinters of El Tatio, northern Chile. Sedimentary Geology 180, 125-147.

Flores, G.E., Reysenbach, A.-L., 2011. Hydrothermal environments, marine. In: J. Reitner and V. Thiel (Editors), Encyclopedia of Geobiology. Springer, pp. 456-466.

Fournier, R.O., 1985. The behavior of silica in hydrothermal solutions. In Berger, B.R., Bethke, P.M. (eds.), Geology and Geochemistry of Epithermal Systems: Reviews in Geology, Society of Economic Geologists, v. 2, 45-61.

Fournier, R.O., Kennedy, B.M., Aoki, M., Thompson, J.M., 1994. Correlation of gold in siliceous sinters with ${ }^{3} \mathrm{He} /{ }^{4} \mathrm{He}$ in hot spring waters of Yellowstone National Park. Geochimica et Cosmochimica Acta 58, 5401-5419.

Fralick, P., David, D.W., Kissin, S.A., 2002. The age of the Gunflint Formation, Ontario, Canada: single zircon U-Pb age determinations. Canadian Journal of Earth Sciences 39, 1085-1091. doi:10.1139/E02-028. 
Franchini, M., Impiccini, A., Lentz, D., Javier Ríos, F., O’Leary, S., Pons, J., Schalamuk, A.I., 2011. Porphyry to epithermal transition in the Agua Rica polymetallic deposit, Catamarca, Argentina: an integrated petrologic analysis of ore and alteration paragenesis. Ore Geology Reviews 41, 49-74.

García Massini, J., Channing, A., Guido, D.M., Zamuner, A.B., 2012. First report of fungi and fungus-like organisms from Mesozoic hot springs. Palaios 27, 55-62.

Garcia-Valles, M., Fernandez-Turiel, J.L., Gimeno-Torrente, D., Saavedra-Alonso, J., Martinez-Manet, S., 2008. Mineralogical characterization of silica sinters from the El Tatio geothermal field, Chile. American Mineralogist 93, 1373-1383.

Gibson, R.A., Sherry, A., Kaur, G., Pancost, R.D., Talbot, H.M., 2014.

Bacteriohopanepolyols preserved in silica sinters from Champagne Pool (New Zealand) indicate a declining temperature gradient over the lifetime of the vent. Organic Geochemistry 69, 61-69.

Goldie, R., 1985. The sinters of Ohaaki and Champagne pools, New Zealand: possible modern analogues of the Hemlo gold deposits. Geoscience Canada 12, 60-64.

Göttlicher, J., Pentinghaus, H.J., Himmel, B., 1998. On the microstructure of geyserites and hyalites, natural hydrous forms of silica. Journal of Sol-Gel Science and Technology 13, $85-88$.

Gray, J.E., Gent, C.A., Snee, L.W., Wilson, F.H., 1997. Epithermal mercury-antimony and gold-bearing vein lodes of southwestern Alaska. Economic Geology Monograph 9, 287305.

Guido, D.M., Campbell, K.A., 2009. Jurassic hot-spring activity in a fluvial setting at La Marciana, Patagonia, Argentina. Geological Magazine 146, 617-622. 
Guido, D.M., Campbell, K.A., 2011. Jurassic hot spring deposits of the Deseado Massif (Patagonia, Argentina): characteristics and controls on regional distribution. Journal of Volcanology and Geothermal Research 203, 35-47.

Guido, D.M., Campbell, K.A., 2012. Diverse subaerial and sublacstrine hot spring settings of the Cerro Negro epithermal system (Jurassic, Deseado Massif), Patagonia, Argentina). Journal of Volcanology and Geothermal Research 229-230, 1-12.

Guido, D.M., Campbell, K.A., 2014. A large and complete Jurassic geothermal field at Claudia, Deseado Massif, Santa Cruz, Argentina. Journal of Volcanology and Geothermal Research 275, 61-70.

Guidry, S.A., Chafetz, H.S., 2003. Anatomy of siliceous hot spring examples from Yellowstone National Park, Wyoming, U.S.A. Sedimentary Geology 157, 71-106. Hamilton, A., 2014. The Textures and Mineralogy of the Kohuamuri Siliceous Sinter, Coromandel Peninsula, and its Economic Potential, unpublished MSc Thesis, The University of Auckland, 180 p.

Hamade, T., Konhauser, T.O., Raiswell, R., Goldsmith, S., Morris, R.C., 2003. Using Ge/Si ratios to decouple iron and silica fluxes in Precambrian banded iron formations. Geology $31,35-38$.

Handley, K.M., Campbell, K.A., 2011. Character, analysis and preservation of biogenicity in terrestrial siliceous stromatolites from geothermal settings. V.C. Tewari and J. Seckbach (eds.), STROMATOLITES: Interaction of Microbes with Sediments, Cellular Origin, Life in Extreme Habitats and Astrobiology 18, 359-381. DOI 10.1007/978-94-007-0397-1_16.

Handley, K.M., Campbell, K.A., Mountain, B.W., Browne, P.R.L., 2005. Abiotic-biotic controls on the origin and development of spicular sinter: in situ growth experiments, Champagne Pool, Waiotapu, New Zealand. Geobiology 3, 93-114. 
Handley, K.M., Turner, S.J., Campbell, K.A., Mountain, B.W., 2008. Silicifying biofilm exopolymers on a hot-spring microstromatolite: templating nanometer-thick laminae. Astrobiology 8, 747-770.

Havig, J.R., Raymond, J., Meyer-Dombard, D.R., Zolotova, N., Shock, E.L., 2011. Merging isotopes and community genomics in a siliceous sinter-depositing hot spring. Journal of Geophysical Research 116, G01005, doi:10.129/2010JG001415.

Henley, R.W., Ellis, A. J., 1983. Geothermal systems ancient and modern: a geochemical review. Earth-Science Reviews 19, 1-50.

Herdianita, N.R., P.R.L. Browne, K.A. Rodgers, K.A. Campbell, 2000. Mineralogical and textural changes accompanying ageing of silica sinter. Mineralium Deposita 35, 48-62.

Hinman, N.W., Walter, M.R., 2005. Textural preservation in siliceous hot spring deposits during early diagenesis: examples from Yellowstone National Park and Nevada, U.S.A. Journal of Sedimentary Research 75, 200-215.

Hofmann, H.J., 1969. Stromatolites from the Proterozoic Animikie and Sibley groups, Ontario. Canadian Geological Survey Paper 68-59, 77 p.

Hoppert, M., 2011. Bacteria. In: J. Reitner and V. Thiel (Editors), Encyclopedia of Geobiology. Springer, pp. 81-88.

Horodyski, R.J., Bloeser, B., Haar, S.V., 1977. Laminated algal mats from a coastal lagoon, Laguna Mormona, Baja California, Mexico. Journal of Sedimentary Petrology 47, 680696.

Huber, R., Eder, W., Heldwein, S., Wanner, G., Huber, H., Rachel, R., Stetter, K.O., 1998. Thermocrinis ruber, gen. nov., sp. nov., a pink-filament-forming hyperthermophilic bacterium isolated from Yellowstone National Park. Applied and Environmental Microbiology 64, 3576-3583. 
Hurwitz, S., Lowenstern, J.B., 2014. Dynamics of the Yellowstone hydrothermal system. Reviews of Geophysics 51, 375-411, doi:10.1002/2014RG000452.

Isaenko, S.I., Shumilova, T.G., Tatarinova, A.V., Yalovik, L.I., 2011. Carbonaceous matter of quartz breccia and geyserites of the Baleiskoe ore field. Doklady Earth Sciences 436, $258-261$.

Jackson, J.A., Mehl, J.P., Neuendorf, K.K., 2007. Glossary of Geology. American Geological Institute, Alexandria, Virginia (online version).

Jones, B., Renaut, R.W., 1996. Influence of thermophilic bacteria on calcite and silica precipitation in hot springs with water temperatures above $90{ }^{\circ} \mathrm{C}$ : evidence from Kenya and New Zealand. Canadian Journal of Earth Sciences 33, 72-83.

Jones, B., Renaut, R.W., 2003. Petrography and genesis of spicular and columnar geyserites from the Whakarewarewa and Orakeikorako geothermal areas, North Island, New Zealand. Canadian Journal of Earth Sciences 40, 1585-1610.

Jones, B., Renaut, R.W., 2004. Water content of opal-A: Implications for the origin of laminae in geyserite and sinter. Journal of Sedimentary Research 74, 117-128.

Jones, B., Renaut, R.W., 2011. Hot springs and geysers. In: J. Reitner and V. Thiel (Editors), Encyclopedia of Geobiology. Springer, pp. 447-451.

Jones, B., Renaut, R.W., Rosen, M.R., 1997a. Biogenecity of silica precipitation around geysers and hot-spring vents, North Island, New Zealand. Journal of Sedimentary Research 67, 88-104.

Jones, B., Renaut, R.W., Rosen, M.R., 1997b. Vertical zonation of biota in microstromatolites associated with hot springs, North Island, New Zealand. Palaios 12, $220-236$. 
Jones, B., Renaut, R.W., Rosen, M.R., 1998. Microbial biofacies in hot-spring sinters: a model based on Ohaaki Pool, North Island, New Zealand. Journal of Sedimentary Research 68, 413-434.

Jones, B., Renaut, R.W., Rosen, M.R., 2000. Stromatolites forming in acidic hot-spring waters, North Island, New Zealand. Palaios 15, 450-475.

Jones, B., Renaut, R.W., Rosen, M.R., 2001a. Taphonomy of silicified filamentous microbes-implications for identification. Palaios 16, 580-592.

Jones, B., Renaut, R.W., Rosen, M.R., 2001b. “Geyser eggs” from Te Whakarewarewatangaoteopetauaawahiao, North Island, New Zealand. Journal of Sedimentary Research 71, 190-204.

Jones, B., Renaut, R.W., Rosen, M.R., 2003. Silicified microbes in a geyser mound: the enigma of low-temperature cyanobacteria in a high-temperature setting. Palaios $18,87-$ 109.

Kashefi, K., Lovley, D.R., 2003. Extending the upper temperature limit for life. Science 301, 934.

Kaur, G., Mountain, B.W., Hopmans, E.C., Pancost, R.D., 2011. Relationship between lipid distribution and geochemical environment within Champagne Pool, Waiotapu, New Zealand. Organic Geochemistry 42, 1203-1215.

Kerr, R.A., 2004. Rainbow of Martian minerals paints picture of degradation. Science 305, $770-771$.

Kesler, S.E., Wilkinson, B.H., 2009. Resources of gold in Phanerozoic epithermal deposits. Economic Geology 104, 623-633.

Kiyokawa, S., Ito, T., Ikehara, M., Kitajima, F., 2006. Middle Archean volcano-hydrothermal sequence: bacterial microfossil-bearing 3.2 Ga Dixon Island Formation, coastal Pilbara terrane, Australia. GSA Bulletin 118, 3-22. doi: 10.1130/B25748.1. 
Knauth, L.P., Lowe, D.R., 2003. High Archean climatic temperature inferred from oxygen isotope geochemistry of cherts in the 3.5 Ga Swaziland Supergroup, South Africa. Geological Society of America Bulletin 115, 566-580.

Knoll, A.H., 1985. Exceptional preservation of photosynthetic organisms in silicified carbonates and silicified peats. Philosophical Transactions of the Royal Society of London. Series B, Biological Sciences 311, 111-122.

Knoll, A.H., Butterfield, N.J., 1989. New window on Proterozoic life. Nature 337, 602-603.

Knoll, A.H., Simonson, B., 1981. Early Proterozoic microfossils and penecontemporaneous quartz cementation in the Sokoman Iron Formation, Canada. Science 211, 478-480.

Knoll, A.H., Swett, K., 1985. Micropaleontology of the Late Proterozoic Veteranen Group, Spitsbergen. Palaeontology 28, 451-473.

Konhauser, K.O., Ferris, F.G., 1996. Diversity of iron and silica precipitation by microbial mats in hydrothermal waters, Iceland: implications for Precambrian iron formations. Geology 24, 323-326.

Konhauser, K.O., Jones, B., Reysenbach, A.-L., Renaut, R.W., 2003. Hot spring sinters: keys to understanding Earth's earliest life forms. Canadian Journal of Earth Sciences 40, 17131724.

Konhauser, K.O., Phoenix, V.R., Bottrell, S.H., Adams, D.G., Head, I.M., 2001. Microbialsilica interactions in modern hot spring sinter: possible analogues for some Precambrian siliceous stromatolites. Sedimentology 48, 415-433.

Krauskopf, K. 1956. Dissolution and precipitation of silica at low temperatures. Geochimica et Cosmochimica Acta 10,1-26.

Krumbein, W.E., 1983. Stromatolites - the challenge of a term in space and time. Precambrian Research 20, 493-531. 
Lalonde, S.V., Konhauser, K.O., Reysenbach, A.-L., Ferris, F.G., 2005. The experimental silicification of Aquificales and their role in hot spring sinter formation. Geobiology 3, $41-52$.

Lau, C.Y., Aitchison, J.C., Pointing, S.B., 2008. Early colonization of themal niches in a silica-depositing hot spring in central Tibet. Geobiology 6, 136-146.

Le Turdu, C., Tiercelin, J.-J., Gibert, E., Travi, Y., Lezzar, K.-E., Richert, J.-P., Gasse, F., Bonnefille, R., Decobert, M., Gensous, B., Jeudy, V., Tamrat, E., Umer Mohammed, M., Martens, K., Atnafu, B., Chernet, T., Williamson, D., Taieb, M., 1999. The Ziway-Shala lake basin system, Main Ethiopian Rift : influence of volcanism, tectonics, and climateforcing on basin formation and sedimentation. Palaeogeography, Palaeoclimatology, Palaeoecology 150, 135-177.

Lowe, D.R., Anderson, K.S., Braunstein, D., 2001. The zonation and structuring of siliceous sinter around hot springs, Yellowstone National Park, and the role of thermophilic bacteria in its deposition. In: Reysenbach, A.M., Voytech, M., Mancinelli, R. (Eds.), Thermophiles: Biodiversity, Ecology and Evolution: Kluwer Academic/Plenum Publishers, New York, 143-166.

Lowe, D.R., Braunstein, D., 2003. Microstructure of high-temperature $\left(>73^{\circ} \mathrm{C}\right)$ siliceous sinter deposited around hot springs and geysers, Yellowstone National Park: the role of biological and abiological processes in sedimentation. Canadian Journal of Earth Sciences 40, 1611-1642.

Lutz, S.J., Caskey, S.J., Mildenhall, D.D., Browne, P.R.L., Johnson, S.D., 2002. Dating sinter deposits in the northern Dixie Valley, Nevada-the paleoseismic record and implications for the Dixie Valley geothermal system. Proceedings of the $27^{\text {th }}$ Workshop on Geothermal Reservoir Engineering, Stanford University, Stanford, California, January 2830, 2002. SGP-TR-171. 
Lynne, B.Y., 2012. Mapping vent to distal-apron hot spring paleo-flow pathways using siliceous sinter architecture. Geothermics 43, 3-24.

Maliva, R.G., Knoll, A.H., Simonson, B.M., 2005. Secular change in the Precambrian silica cycle: insights from chert petrology. GSA Bulletin 117, 835-845.

Marin-Carbonne, J., Chaussidon, M., Robert, F., 2012. Micrometer-scale chemical and isotopic criteria $(\mathrm{O}$ and $\mathrm{Si})$ on the origin and history of Precambrian cherts: implications for paleo-temperature reconstructions. Geochemica et Cosmochimica Acta 92, 129-147.

Marin-Carbonne, J., Robert, F., Chaussidon, M., 2014. The silicon and oxygen isotope compositions of Precambrian cherts: a record of ocean paleo-temperatures ? Precambrian Research 247, 223-234.

McCollom, T.M., Hynek, B.M., 2005. A volcanic environment for bedrock diagenesis at Meridiani Planum on Mars. Nature 438, 1129-1131.

McKenzie, E.J., Brown, K.L., Cady, S.L., Campbell, K.A., 2001. Trace metal chemistry and silicification of microorganisms in geothermal sinter, Taupo Volcanic Zone, New Zealand. Geothermics 30, 483-502.

McLoughlin, N., Wilson, L.A., Brasier, M.D., 2008. Growth of synthetic stromatolites and wrinkle structures in the absence of microbes_-implications for the early fossil record. Geobiology 6, 95-105.

Mohr, K.I., Brinkmann, N., Friedl, T., 2011. Cyanobacteria. In: J. Reitner and V. Thiel (Editors), Encyclopedia of Geobiology. Springer, pp. 306-311.

Mountain, B.W., Benning, L.G., Boerema, J.A., 2003. Experimental studies on New Zealand hot spring sinters: rates of growth and textural development. Canadian Journal of Earth Sciences 40, 1643-1667.

Nisbet, E.G., Sleep, N.H., 2001. The habitat and nature of early life. Nature 409, 1083-1091. 
Nordlie, B.E., Colony, W.E., 1973. Fumarole with periodic water fountaining, Volcan Alcedo, Galapagos Islands. GSA Bulletin 84, 1709-1720.

Oehler, J.H., 1972. "Stromatoloids" from Yellowstone Park, Wyoming. Geological Society of America, Cordilleran Section, Honolulu 1972 Annual Meeting Program, p. 212-213.

Orange, F., Westall, F., Disnair, J.-R., Prieur, D., Bienvenu, N., Le Romancer, M., Défarge, C., 2009. Experimental silicification of the extremophilic Archaea Pyrococcus abyssi and Methanocaldococcus jannaschii: applications in the search for evidence of life in early Earth and extraterrestrial rocks. Geobiology 7, 403-418.

Owen, R.B., Renaut, R.W., Behrensmeyer, A.K., Potts, R., 2014. Quaternary geochemical stratigraphy of the Kedong-Olorgesailie section of the southern Kenya Rift Valley. Palaeogeography, Palaeoclimatology, Palaeoecology 396, 194-212.

Palinska, K.A., Thomasius, C.F., Marquardt, J., Golubic, S., 2006. Phylogenetic evaluation of cyanobacteria preserved as historic herbarium exsiccate. International Journal of Systematic and Evolutionary Microbiology 56, 2253-2263.

Pancost, R.D., Pressley, S., Coleman, J.M., Talbot, H.M., Kelly, S.P., Farrimond, P., Schouten, S., Benning, L., Mountain, B.W., 2006. Composition and implications of diverse lipids in New Zealand geothermal sinters. Geobiology 4, 71-92.

Pankhurst, R., Riley, T., Fanning, C.Y., Kelley, S., 2000. Episodic silicic volcanism in Patagonia and the Antarctic Peninsula: chronology of magmatism associated with the break-up of Gondwana. Journal of Petrology 41, 605-625.

Peng, X., Jones, B., 2012. Rapid precipitation of silica (opal-A) disguises evidence of biogenicity in geothermal deposits: case study from Dagunguo hot spring, China. Sedimentary Geology 257-260, 45-62.

Pentecost, A., 2005. Travertine. Springer, Berlin, 445 p. 
Planavsky, N., Rouxel, O., Bekker, A., Shapiro, R., Fralick, P., Knudsen, A., 2009. Ironoxidizing microbial ecosystems thrived in late Paleoproterozoic redox-stratified oceans. Earth and Planetary Science Letters 286, 230-242.

Pouba, Z., 1978. Stromatolity, gejzfrity nebo stiriolty v ceském proterozoiku? [Stromatolites, geyserites or stiriolites in the Bohemian Proterozoic?]. In Pouba, Z. (ed.), Korelace Proterozoickych a Paleozoickych Stratiformních Lozisek [Correlation of the Proterozoic and Paleozoic Stratiform Deposits]: Prague, Charles University, Institute of Geological Sciences, v. 5, p. 71-81.

Pouba, Z., Kríbek, B., Pudilova, M., 2000. Stromatolite-like cherts in the Barrandian Upper Proterozoic: a review. Bulletin of the Czech Geological Survey 75(3), 285-296.

Prescott, M.L., Harley, P.J., Klein, A.D., 2002. Microbiology, $5^{\text {th }}$ edition. McGraw-Hill Inc., $1026 \mathrm{p}$.

Rasmussen, B., 2000. Filamentous microfossils in a 3235-million-year-old volcanogenic massive sulfide deposit. Nature 405, 676-679.

Renaut, R.W., Jones, B., 2011. Hydrothermal environments, terrestrial. In: J. Reitner and V. Thiel (Editors), Encyclopedia of Geobiology. Springer, pp. 467-479.

Reitner, J., 2011. Biofilms. In: J. Reitner and V. Thiel (Editors), Encyclopedia of Geobiology. Springer, pp. 134-135.

Reysenbach, A.-L., Cady, S.L., 2001. Microbiology of ancient and modern hydrothermal systems. TRENDS in Microbiology 9, 79-86.

Reysenbach, A.-L., Voyteck, M., Mancinelli, R., 2001. Thermophiles: Biodiversity, Ecology, and Evolution. Kluwer Academic-Plenum Publishers, New York, 205 p.

Reysenbach, A.-L., Wickham, G.S., Pace, N.R., 1994. Phylogenetic analysis of the hyperthermophilic pink filament community in Octopus Spring, Yellowstone National Park. Applied Environmental Microbiology 60, 2113-2119. 
Rice, C.M., Trewin, N.H., 1988. A Lower Devonian gold-bearing hot spring system, Rhynie, Scotland. Transactions, Institution of Mining and Metallurgy (Section B: Applied Earth Science) 97, B141-B144.

Rice, C.M., Trewin, N.H., Anderson, L.I., 2002. Geological setting of the Early Devonian Rhynie cherts, Aberdeenshire, Scotland: an early terrestrial hot-spring system. Journal of the Geological Society, London 159, 203-214.

Richardson, N.J., Underhill, J.R., 2002. Controls on the structural architecture and sedimentary character of syn-rift sequences, North Falkland Basin, South Atlantic. Marine and Petroleum Geology 19, 417-443.

Riley, T., Leat, P., Pankhurst, R., and Harris, C., 2001. Origin of large volume rhyolitic volcanism in Antarctic Peninsula and Patagonia by crustal melting. Journal of Petrology $42,1043-1065$.

Rimstidt, J.D., Cole, D.R., 1983. Geothermal mineralization I: the mechanism of formation of the Beowawe, Nevada, siliceous sinter deposit. American Journal of Science 283, 861875.

Rodgers, K.A., Browne, P.R.L., Buddle, T.F., Cook, K.L., Greatrex, R.A., Hampton, W.A., Herdianita, N.R., Holland, G.R., Lynne, B.Y., Martin, R., Newton, Z., Pastars, D., Sannazarro, K.L. and Teece, C.I.A., 2004. Silica phases in sinters and residues from geothermal fields of New Zealand. Earth-Science Reviews 66, 1-61.

Rothschild, L.J., Mancinelli, R.L., 2001. Life in extreme environments. Nature 409, 1092 1101

Rowland, J.V., Simmons, S. 2012. Hydrologic, magmatic, and tectonic controls on hydrothermal flow, Taupo Volcanic Zone, New Zealand: implications for the formation of epithermal vein deposits. Economic Geology 107, 427-457. 
Ruff, S.W., Farmer, J.D., Calvin, W.M., Herkenhoff, K.E., Johnson, J.R., Morris, R.V., Rice,

M.S., Arvidson, R.E., Bell III, J.F., Christensen, P.R., Squyres, S.W., 2011.

Characteristics, distribution, origin and significance of opaline silica observed by Spirit rover in Gusev Crater, Mars. Journal of Geophysical Research 116, E00F23.

Schalamuk, I., Rubia, M., Genini, A., Fernández, R., 1997. Jurassic epithermal Au-Ag deposits of Patagonia, Argentina. Ore Geology Reviews 12, 173-186.

Schinteie, R., Campbell, K.A., Browne, P.R.L., 2007. Microfacies of stromatolitic sinter from acid-sulphate-chloride springs at Parariki Stream, Rotokawa geothermal field, New Zealand. Palaeontologia Electronica 10, issue 1, 4A, 1-33; http://palaeoelectronica.org/paleo/2007_1/sinter/index.html.

Schubotz, F., Meyer-Dombard, D.R., Bradley, A.S., Fredricks, H.F., Hinrichs, K.-U., Shock, E.L., Summons, R.E., 2013. Spatial and temporal variability of biomarkers and microbial diversity reveal metabolic and community flexibility in streamer biofilm communities in the Lower Geyser Basin, Yellowstone National Park. Geobiology doi:10.111/gbi.12051.

Semikhatov, M.A., Gebelein, C.D., Cloud, P., Awramik, S.M., Benmore, W.C., 1979.

Stromatolite morphogenesis: progress and problems. Canadian Journal of Earth Science $19,992-1015$.

Setchell, W.A., 1903. The upper temperature limits of life. Science 17, 934-937.

Sherlock, R.L., Tosdal, R.M., Lerhman, N.J., Graney, J.R., Losh, S., Jowett, E.C., Kesler, S.E., 1995. Origin of the McLaughlin mine sheeted vein complex: metal zoning, fluid inclusion, and isotopic evidence. Economic Geology 90, 2156-2181.

Siever, R., 1992. The silica cycle in the Precambrian. Geochimica et Cosmochimica Acta 56, $3265-3272$. 
Sillitoe, R.H., 1993. Epithermal models: genetic types, geometrical controls and shallow features. In: Kirkham, R.V., Sinclair, W.D., Thorpe, R.I., Duke, J.M. (Eds.), Mineral Deposits Modeling: Special Paper of the Geological Association of Canada, 40, 403-417.

Simmons, S.F., Keywood, M., Scott, B.J., Keam, R.F., 1993. Irreversible change of the Rotomahana-Waimangu hydrothermal system (New Zealand) as a consequence of a volcanic eruption. Geology 21, 643-646.

Skirnisdottir, S., Hreggvidsson, G.O., Hjörleifsdottir, S., Marteinsson, V.T., Petursdottir, S.K., Holst, O., Kristjansson, J.K., 2000. Influence of sulfide and temperature on species composition and community structure of hot spring microbial mats. Applied and Environmental Microbiology 66, 2835-2841.

Sommers, M.G., Awramik, S.M., 1996. Abiogenic "stromatolites" from the Gunflint IronFormation; microstructural criteria for determining abiogenic vs. biogenic stromatolites. Abstracts with programs, Geological Society of America 28/7, 174.

Soriano, S., 1973. Flexibacteria. Annual Reviews in Microbiology 27, 155-170.

Squyres, S.W., Arvidson, R.E., Ruff, S., Gellert, R., Morris, R.V., Ming, D.W., Crumpler, L., Farmer, J.D., Des Marais, D.J., Yen, A., McLennan, S.M., Calvin, W., Bell III, J.F., Clark, B.C., Wang, A., McCoy, T.J., Schmidt, M.E., de Souza, Jr., P.A., 2008. Detection of silica-rich deposits on Mars. Science 320, 1063-1067.

Stetter, K.O., 1996. Hyperthermophilic procaryotes. FEMS Microbiology Reviews 18, 149158.

Sturchio, N.C., Dunkley, P.N., Smith, M., 1993. Climate-driven variations in the geothermal activity of the northern Kenya Rift Valley. Nature 362, 233-234.

Sugitani, K., 1992. Geochemical characteristics of Archean cherts and other sedimentary rocks in the Pilbara block, Western Australia: evidence for Archean seawater enriched in hydrothermally-derived iron and silica. Precambrian Research 57, 21-47. 
Takai, K., Nakamura, K., Toki, T., Tsunogai, U., Miyazaki, M., Miyazaki, J., Hirayama, H., Nakagawa, S., Nunoura, T., Horikoshi, K., 2008. Cell proliferation at $122{ }^{\circ} \mathrm{C}$ and isotopically heavy $\mathrm{Ch} 4$ production by a hyperthermophilic methanogen under highpressure cultivation. Proceedings of the National Academy of Sciences U.S.A. 105, 10949-10954.

Takacs, C.D., Ehringer, M., Favre, R., Cermola, M., Eggertsson, G., Palsdottir, A., Reysenbach, A.-L., 2001. Phylogenetic characterization of the blue filamentous bacterial community from an Icelandic geothermal spring. FEMS Microbiology Ecology 35, 123128.

Takacs-Vesbach, C., Inskeep, W.P., Jay, Z.J., Herrgard, M.J., Rusch, D.B., Tringe, S.G., Kozubal, M.A., Hamamura, N., Macur, R.E., Fouke, B.W., Reysenbach, A.-L., McDermott, T.R., Jennings, R. deM., Hengartner, N.W., Xie, G., 2013. Metagenome sequence analysis of filamentous microbial communities obtained from geochemically distinct geothermal channels reveals specialization of three Aquificales lineages. Frontiers in Microbiology 4,\#84, doi: 10.3389/fmicb.2013.00084.

Thiel V., 2011a. Archaea. In: J. Reitner and V. Thiel (Editors), Encyclopedia of Geobiology. Springer, pp. 64-68.

Thiel V., 2011b. Chemolithotrophy. In: J. Reitner and V. Thiel (Editors), Encyclopedia of Geobiology. Springer, pp. 271-272.

Tice, M.M., Lowe, D.R., 2004. Photosynthetic microbial mats in the 3416-Myr-old ocean. Nature 431, 549-552.

Tobler, D.J., Stefánsson, A., Benning, L.G., 2008. In-situ grown silica sinters in Icelandic geothermal areas. Geobiology 6, 481-502. 
Trewin, N.H., 1993. Depositional environment and preservation of biota in the Lower Devonian hot-springs of Aberdeenshire, Scotland. Transactions of the Royal Society of Edinburgh: Earth Sciences 84, 433-442.

Trewin, N.H., 1996. The Rhynie Chert: An early Devonian ecosystem preserved by hydrothermal activity. In: Bock, G.R., Goode, G.A. (Eds.), 131-149.

Trewin, N.H., Rice, C., 2003. Preface. Transactions of the Royal Society of Edinburgh: Earth Sciences 94, 283-284.

Tyler, S.A., Barghoorn, E.S., 1954. Occurrence of structurally preserved plants in PreCambrian rocks of the Canadian Shield. Science 119, 606-608.

Urusov, V.S., Shvanskaya, L.V., Bychkov, A. Yu., Mokhov, A.V., Labutova, E.A., 2008.

Microstructure investigations of Kamchatka geyserites. Moscow University Bulletin 63, $311-319$.

van den Boorn, S.H.J.M., van Bergen, M.J., Vroon, P.Z., de Vries, S.T., Nijman, W., 2010. Silicon isotope and trace element constraints on the origin of $\sim 3.5 \mathrm{Ga}$ cherts: implications for Early Archean marine environments. Geochimica et Cosmochimica Acta 74, 10771103.

van den Boorn, S., van Bergen, M.J., Vroon, P.Z., de Vries, S.T., Nijman, W., 2007. Dual role of seawater and hydrothermal fluids in Early Archean chert formation: evidence from silicon isotopes. Geology 35, 939-942.

Van Vliet-Lanoë, B., Guðmundsson, Å., Guillou, H., Duncan, R.A., Genty, D., Ghaleb, B., Guoy, S., Récourt, P., Scaillet, S., 2007. Limited glaciation and very early deglaciation in central Iceland - implications for climate change. Comptes Rendu Geoscience 339, 1-12. Vikre, P.G., 2007. Sinter-vein correlations at Buckskin Mountain, National District, Humboldt County, Nevada. Economic Geology 102, 193-224. 
Walsh, M.M., Lowe, D.R., 1999. Modes of accumulation of carbonaceous matter in the early Archean: A petrographic and geochemical study of the carbonaceous cherts of the Swaziland Supergroup. In Lowe, D.R., Byerly, G.R. (eds.), Geologic Evolution of the Barberton Greenstone Belt, South Africa, Geological Society of America Special Papers 329, 115-132. doi:10.1130/0-8137-2329-9.115.

Walter, M.R., 1972. A hot spring analog for the depositional environment of Precambrian iron formations of the Lake Superior region. Economic Geology 67, 965-980.

Walter, M.R., 1976a. Geyserites of Yellowstone National Park: An example of abiogenic “stromatolites”. In: Walter, M.R. (Ed.), Stromatolites: Elsevier, Amsterdam, 87-112. Walter, M.R., 1976b. Hot-spring sediments in Yellowstone National Park. In: Walter, M.R. (Ed.), Stromatolites: Elsevier, Amsterdam, 489-498.

Walter, M.R., Bauld, J., Brock, T.D., 1972. Siliceous algal and bacterial stromatolites in hot spring and geyser effluents of Yellowstone National Park. Science 178, 402-405.

Walter, M.R., Des Marais, D., Farmer, J.D., Hinman, N.W., 1996. Lithofacies and biofacies of mid-Paleozoic thermal spring deposits in the Drummond Basin, Queensland, Australia. Palaios 11, 497-518.

Walter, M.R., Grotzinger, J.P., Schopf, J.W., 1992. Proterozoic stromatolites. In Schopf, J.W., Klein, C. (Eds.), The Proterozoic Biosphere: A Multidisciplinary Study. Cambridge University Press, Cambridge, U.K., 253-260.

Watts-Henwood, N., 2015. Textures and Mineralogy of Siliceous Hot-spring Deposits at Geyser Valley, Wairakei, Taupo Volcanic Zone, New Zealand. Unpublished MSc thesis, The University of Auckland.

Weed, W.H., 1889. The diatom marshes and diatom beds of the Yellowstone National Park. Botanical Gazette, May 1889, 117-120. 
Weissberg, B., 1969. Gold-silver ore-grade precipitates from New Zealand thermal waters. Economic Geology 64, 95-108.

Westall, F., 2011. Early life. In Gargaud, M., Lopéz-Garcia, P., Martin, H. (Eds.), Origins of Life, an Astrobiological Perspective. Cambridge University Press, Cambridge, U.K., 391413.

Westall, F., Cavalazzi, B., 2011. Biosignatures in rocks. In: J. Reitner and V. Thiel (Editors), Encyclopedia of Geobiology. Springer, pp. 189-201.

Westall, F., Cavalazzi, B., Laurence, L., Marrocchi, Y., Rouzaud, J.-N., Simionovici, A., Salome, G., MacLean, L., Wirick, S., Hofmann, A., Meibom, A., Robert, F., Defarge, C., 2011. Implications of in situ calcification for photosynthesis in an approximately $3.3 \mathrm{Ga}-$ old microbial biofilm from the Barberton greenstone belt, South Africa. Earth and Planetary Science Letters 310, 468-479.

Westall, F., de Ronde, C.E.J., Southam, G., Grassineau, N., Colas, M., Cockell, C., Lammer, H., 2006. Implications of a 3.472-3.333 Gyr-old subaerial microbial mat from the Barberton greenstone belt, South Africa for the UV environmental conditions on the early Earth. Philosophical Transactions of the Royal Society B 361, 1857-1896.

Westall, F., Steele, A., Toporski, J., Walsh, M., Allen, C., Guidry, S., McKay, D., Gibson, E., Chafetz, H., 2000. Polymeric substances and biofilms as biomarkers in terrestrial materials: implications for extraterrestrial samples. Journal of Geophysical Research 105(E10), 24,511-24,527.

White, D.E., Brannock, W.W., Murata, K.J., 1956. Silica in hot springs. Geochimica et Cosmochimica Acta 10, 27-57.

White, D.E., Thompson, G.A., Sandberg, C.H., 1964. Rocks, structure, and geologic history of Steamboat Springs thermal area, Washoe County, Nevada. U.S. Geological Survey Professional Paper 458-B, 63 p. 
Winter, B.L., Knauth, L.P., 1992. Stable isotope geochemistry of cherts and carbonates from the 2.0-Ga Gunflint Iron Formation - implications for the depositional setting and the effects of diagenesis and metamorphism. Precambrian Research 59, 283-313.

Zhou, B., Ren, E., Sherriff, B.L., Yao, Y., 2013. Multinuclear NMR study of Cs-bearing geyserites of the Targejia hot spring cesium deposit in Tibet. American Mineralogist 98, 907-913.

Zimmerman, B.S., Larson, P.B., 1994. Epithermal gold mineralization in a fossil hot spring system, Red Butte, Oregon. Economic Geology 89, 1983-2002.

\section{FIGURE AND TABLE CAPTIONS}

Figure 1. Typical geyserite types and their zonation in near-vent environments of siliceous hot springs at Yellowstone National Park (YNP), Wyoming, U.S.A. and Taupo Volcanic Zone (TVZ), North Island, New Zealand. (A) Geysers manifest in two styles, fountain geysers and, shown here, cone geysers (Braunstein and Lowe, 2001); White Dome Geyser, Firehole Lake Drive, YNP. (B) Botryoidal, knobby, layered masses of geyserite accumulate (up to 2-3 m thick) around geysers and spring-vents of siliceous hot springs ( $<15 \mathrm{~m}$ from vent source); Te Puia geyser mound, TVZ. (C) Crested Pool, Sentinel Meadows, YNP, illustrating a boiling, non-surging vent-pool rimmed with spicular and nodular geyserite. Other morphotypes of high temperature $\left(>75^{\circ} \mathrm{C}\right)$ siliceous sinter in relation to spring hydrodynamics are listed and figured in Braunstein and Lowe (2001). (D) Cross-sectional view of geyserite rim ( $25 \mathrm{~cm}$ thick) at Twin Geyser, Sentinel Meadows, YNP, showing spicular (s) fabric in inner poolward face, transitioning to columnar (c) and nodular (N) textures with distance from the vent pool margin. (E) Plan view of fresh spicular (s) and 
nodular (N) geyserite forming at Twin Geyser, Sentinel Meadows, YNP. (F) Cross-section of stratiform (St) to cumulate (wavy) geyserite, overlain by spicular (Sp) geyserite from Subrecent sinter float blocks in a landslide deposit overlying a fumarole field, Paeroa Fault, Te Kopia, TVZ. (G) Hot pool with particulate stratiform geyserite lining pool bottom and proximal outflow channel (flow direction to left); light gray siliceous precipitate also coats flow-oriented twigs; West Thumb, YNP. (H) Diamond Geyser, Orakei Korako, TVZ, during active period ( 1997-2003), with light yellow-colored, stratiform geyserite lining proximal slope outflow channel and nodular geyserite building up vent mound area. (I) Diamond Geyser in 2007 after several years of minimal spring discharge at lower temperatures, showing growth of thick, colorful, photosynthetic bacterial mats at base and on lower proximal slope of mound. (J) Subrecent pseudocolumnar to columnar geyserite (white, light gray-colored), overlain by reddish brown, wavy laminated to conical tufted (arrow) siliceous sinter, indicating a stratigraphic transition from high-temperature $\left(>75^{\circ} \mathrm{C}\right)$ to moderate temperate $\left(\sim 55-45^{\circ} \mathrm{C}\right)$ hot-spring environments; Geyser Valley, Wairakei, TVZ.

Figure 2. Schematic cross-section of a near-neutral $\mathrm{pH}$, alkali chloride, Si-bearing hot spring and its associated siliceous sinter fabrics in an environmental temperature gradient from nearboiling conditions at the vent to tepid-ambient conditions in surrounding, geothermally influenced marsh areas. These sinter textures and their microbial associations are grouped in proximal, middle and distal apron facies assemblages in Table 1. Detailed descriptions of sinter and travertine textures may be found in Walter (1976a, b), Cady and Farmer (1996), Farmer (2000), Campbell et al. (2001), Lowe et al. (2001), Pentecost (2005), Lowe and Braunstein (2003), Guido and Campbell (2011), Lynne (2012), Drake et al. (2014), and Guido and Campbell (2014). Figure modified from Guido and Campbell (2011). 
Figure 3. Worldwide distribution map of modern and fossil geyserite occurrences.

Quaternary to Recent sinters with reported geyserites are shown as black circles, Cenozoic geyserites as black squares, Mesozoic geyserites as black stars, and Paleozoic geyserites as black triangles. Compiled from White et al. (1964), Nordlie and Colony (1973), Walter (1976a, b), Rimstidt and Cole (1983), Cuneen and Sillitoe (1989), Sturchio et al. (1993), Trewin (1996), Walter et al. (1996), Jones and Renaut (1996, 2003, 2004), Jones et al. (1997), Göttlicher et al. (1998), Le Turdu et al. (1999), Lutz et al. (2002), Fayers and Trewin (2004), Fernandez-Turiel et al. (2005), Hinman and Walter (2005), Darling and Spero (2007), Van Vliet-Lanöe et al. (2007), Garcia-Valles et al. (2008), Lau et al. (2008), Urusov et al. (2008), Ertel (2009), Guido and Campbell (2009, 2014), Boudreau and Lynne (2012), Peng and Jones (2012), Hamilton (2014), Owen et al. (2014), and unpublished data. For additional, possible, global sinter locations see Channing and Edwards (2013).

Figure 4. Geologic map of the Deseado Massif volcanic region of the Chon Aike silicic large igneous province, Patagonia, Argentina, with light gray shaded areas representing Jurassic volcanics, dark gray demarcating pre-Jurassic rocks, and white encompassing postJurassic rocks. The regionally extensive Middle-Late Jurassic volcanic Bahía Laura Complex (Féraud et al., 1999; Riley et al., 2001) hosts widespread epithermal mineralization of Late Jurassic age (Schalamuk et al., 1997). Location of the Claudia paleo-geothermal field (Guido and Campbell, 2014), containing the fossil geyserites described in this study, is in the easternmost portion of the Southern Belt epithermal mineralization trend. See Guido and Campbell (2011) for details of the regional alignment of Jurassic hot springs with epithermal mineralization, and for names of the 25 travertine and/or sinter localities, shown here as letter abbreviations adjacent to red boxes that are sized according to relative areal extent of a given paleo-geothermal field. The associated world-class Cerro Vanguardia mine is positioned 
about $20 \mathrm{~km}$ to the NW of Claudia, with published mineral resources of 4.72 million ounces (Moz) Au and 40 Moz Ag (AngloGold Ashanti, 2012), and an estimated total Au resource of 7.8 Moz (Guido and Campbell, 2014).

Figure 5. Geology of the Claudia geothermal system and Cerro Vanguardia mining property to the NW. The sequence is composed of the middle to upper Jurassic Bahía Laura volcanic complex units (Bajo Pobre, Chon Aike and La Matilde formations), which are partially covered by Cretaceous continental sediments (Baqueró Formation), Cenozoic marine strata (Monte León Formation), Quaternary gravels (La Avenida Formation), plateau basalts (La Angelita Formation), and Recent alluvium. Green boxes indicate distribution of hot spring deposits at Claudia. Locations of the Claudia geyseritic sinters are shown as (a) La Calandria Sur and (b) Loma Alta. For more detailed discussion of the regional geologic context and outcrop descriptions of the sinter sites see Guido and Campbell (2014).

Figure 6. Spatial distribution, geometry and morphology of the Late Jurassic Claudia sinter mound deposits at La Calandria Sur compared with siliceous hot-spring vent mounds active today in Yellowstone National Park (U.S.A.) and New Zealand. A) Satellite image (Google Earth) of in situ mounds at La Calandria Sur. Three interpreted vent areas are labeled with arrows; position and view direction from which Figure 6B photograph was taken is shown by open circle with oriented thin arrow pointing toward NE. B) View to the ENE (see circle with thin arrow in A) of three inferred vent mounds of sinter (arrows) at La Calandria Sur. C) Overview of actively forming siliceous geyser vent mounds at Sentinel Meadows, Yellowstone National Park, Wyoming, U.S.A. D) Mound geometry detail of one of the Jurassic Claudia sinter mounds at La Calandria Sur showing overall conical morphology and vertical to sub-vertical tubular hole ( $40 \mathrm{~cm}$ diameter) inferred as a vent conduit. E) Modern 
Lady Knox Geyser vent mound, Wai-O-Tapu geothermal area, New Zealand, of similar dimensions and morphology to Jurassic mound in D, including hollow conduit feature. F) Detail of an inferred fossil proximal channel (light-colored) in a Claudia sinter mound deposit at La Calandria Norte. G) Intermittently active, proximal outflow channel of Diamond Geyser, Orakei Korako, New Zealand.

Figure 7. Claudia Jurassic geyseritic macrotextures compared with Holocene geyserites from the Taupo Volcanic Zone (TVZ), North Island, New Zealand, using descriptive terminology of Walter et al. (1992) for Proterozoic stromatolites. A) Columnar geyserite in ex situ block (\#127) from Loma Alta displaying parallel to moderately divergent, bifurcate to lateral branching with moderately convex, relatively uniform laminae stacked in slender columns. B) Similar texture as displayed in A except columns vary from slender to somewhat ragged in outer form; sub-Recent northern Wai-O-Tapu sample, TVZ. C \& D) Nodular geyserite surface from La Calandria Sur sinter mound (C, \#LC207A) and modern Diamond Geyser vent mound area, Orakei Korako, TVZ (D). E \& F) Cross-sectional views of encrusting, nodular geyserites from La Calandria Sur mound (E, \#207B) and Soda Fountain vent area, Orakei Korako, TVZ (F), exhibiting cumulate to pseudocolumnar morphology of relatively uniform laminae that are gently to mostly moderately convex, in places steep. Cumulate fabrics vary from bulbous to rectangular to rhombic in outline. G \& H) Coalesced columns of overall stubby morphology with relatively uniform, moderately convex laminae, from Loma Alta geyseritic block (G, \#127) and Diamond Geyser vent mound, Orakei Korako, TVZ (H). Note horizon of spicular geyserite in H. I \& J) Coalesced pseudocolumnar to anastomosed columns of stubby to somewhat slender morphology, with moderately to steeply convex, relatively uniform laminae, from Loma Alta geyseritic block (I, \#C110) and northern Wai-O-Tapu geyserite mound, TVZ (J). K \& L) "Ripple films" of silica coatings 
found rarely on steep, proximal mound outflow areas at La Calandria Sur (K, location LCS185) and commonly on Holocene TVZ geyserite surfaces, including sub-Recent Menagerie geyser mounds, Geyser Valley (L) (hand lens scale $=2.5 \mathrm{~cm}$ diameter).

Figure 8. Claudia Jurassic geyserite microtextures compared with Holocene examples from the Taupo Volcanic Zone (TVZ), North Island, New Zealand, and Yellowstone National Park (YNP), U.S.A., illuminated with plane polarized light microscopy, and described using stromatolite terminology of Walter et al. (1992). A \& B) Parallel to moderately divergent, bifurcate, lateral and anastomosed branching of slender columns of uniform to micro-crosslamination, with some cornices and bridges evident between columns; from Loma Alta ex situ block (A, \#127C) and Daniel Geyser, northern Wai-O-Tapu, TVZ (B). C \& D) Moderately divergent, coalesced to anastomosed branching columns comprising flat to moderately convex, smooth to ragged, micro-cross-laminated horizons, with cornices and bridges ornamenting columns, interspersed with steeply convex slender columns (spicular microtexture, arrows); from Loma Alta ex situ block (C, \#127A) and encrusting a geyserite bead ("geyser egg”) from Bead Geyser, YNP, U.S.A. E) Nodular texture in a Loma Alta ex situ geyserite block \#C110C; white rectangular outline showing location of (F) detail. (F) Geyserite nodule of \#C110C comprising densely packed, pillar-like tubular structures. Boxed areas indicate laser micro-Raman analyses shown in Figure 8A-B. (G) Detail of crowded, parallel to slightly radiating, tubular structures ( $\sim 8 \mu \mathrm{m}$ diameter), partially filled with reddish to brown to black material, as well as their transparent molds, in a nodule $\sim 2.5 \mathrm{~mm}$ high. $(\mathrm{H}$ \& I) Detail of two coalesced geyserite columns (\#C110) in plane-polarized light $(\mathrm{H})$ and cross-polarized light (I), the latter showing fine laminae (arrows) of microcrystalline quartz, faint micro-cross-lamination (mcl), and a vug (v) external to the feature filled with mesocrystalline quartz. (J) Detail of fine lamination of (I) showing the overall 
microcrystalline texture with micro-porosity parallel to geyserite laminae, now filled with mesocrystalline quartz (sensu Maliva et al., 2005); cross-polarized light.

Figure 9. Laser micro-Raman analyses of Claudia tubular micro-inclusions in Loma Alta geyserite sample \#C110C. (A) Laser micro-Raman spatial distribution map of carbonaceous matter (green), anatase (blue) and quartz (yellow and orange) in a tubular structure (inferred microbial filament, see text) shown in Figure 8E-G. (B) Raman intensity spectra (smoothed) showing wave-number peaks for quartz (orange, topmost), carbonaceous matter (green, middle), and anatase (blue, lowermost). Raman spectrometry was undertaken using a WITec Alpha500 RA system with a green laser ( $\lambda=532 \mathrm{~nm}, \mathrm{Nd}$ :YAG frequency doubled laser) at Centre de Biophysique Moléculaire, Orléans. The sampling scanning configuration produced a laser spot size of $\sim 850 \mathrm{~nm}$, with laser power set at $5 \mathrm{~mW}$ at the surface, at a spectral range of $\sim 4000 \mathrm{~cm}^{-1}$ and a resolution of $\sim 3 \mathrm{~cm}^{-1}$, given by the ratio scan size over the number of pixels.

Figure 10. Polished rock slabs from Late Jurassic, ex situ, Loma Alta geyserite blocks (\#C110A) at Claudia, Deseado Massif volcanic province, Patagonia, Argentina. A \& B) Stratigraphic relationships of varied geyseritic textures. Labeled textures include wavy stratiform, bulbous, spicular, nodular, fragmental, columnar, pseudocolumnar.

Table 1. Diversity of textures of (paleo)environmental significance within siliceous sinter (S) and travertine (T) hot-spring deposits, grouped into facies (vent to marsh) and facies associations (proximal, middle and distal apron). Typical geyserite textures are shaded gray. Microbial fossil associations are also shown. HCS, hummocky cross-stratification. Data 
derived from Cady and Farmer (1996), Farmer (2000), Braunstein and Lowe (2001), Guido et al. (2010), Guido and Campbell (2011, 2012), and Drake et al. (2014). 


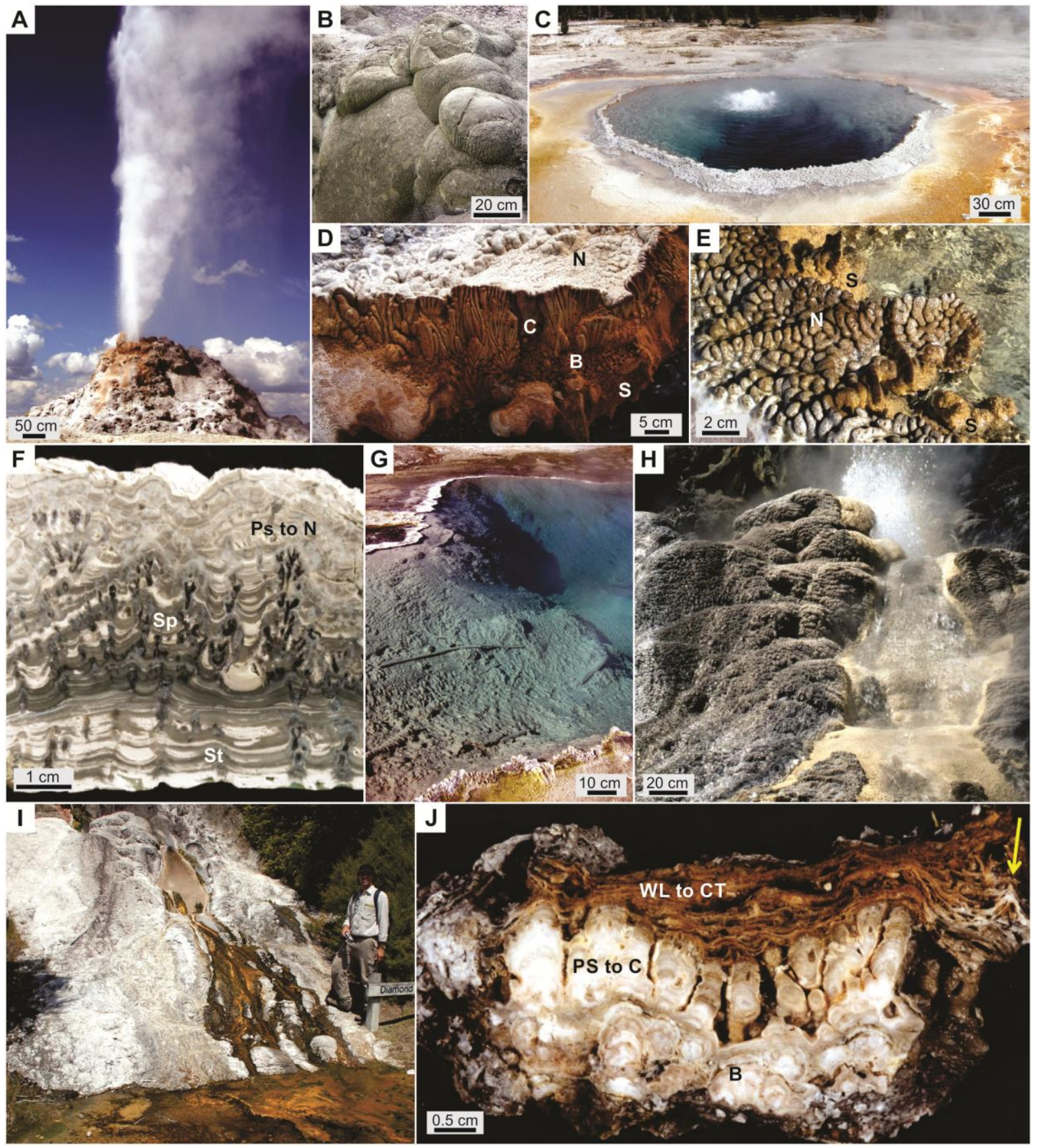

Figure 1 


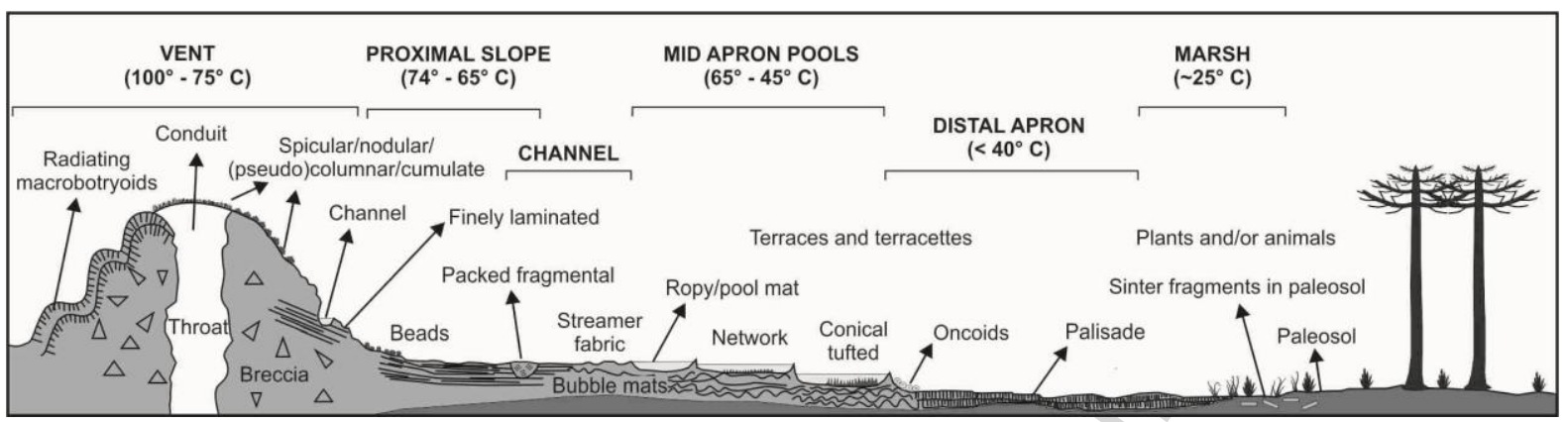

Figure 2 


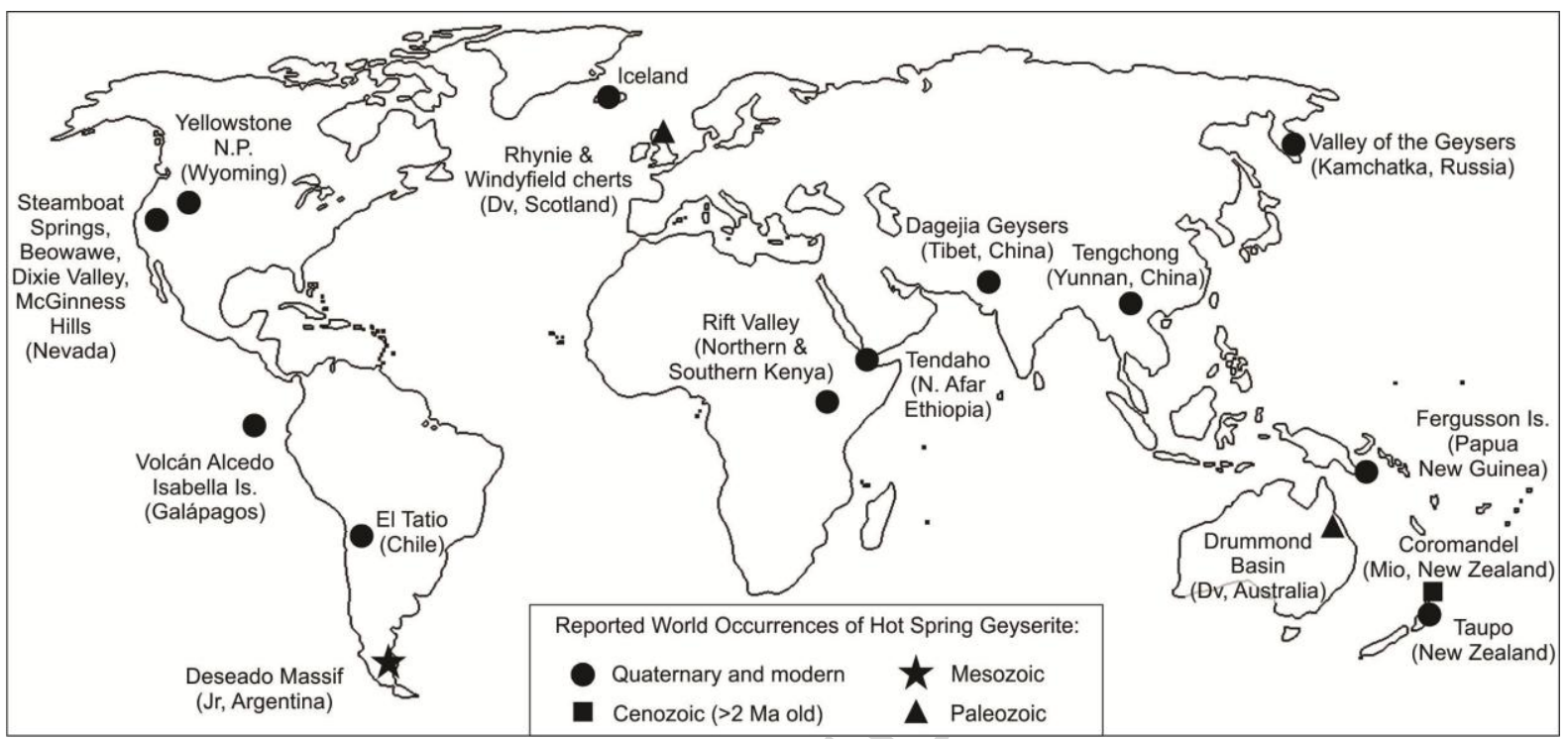

Figure 3 


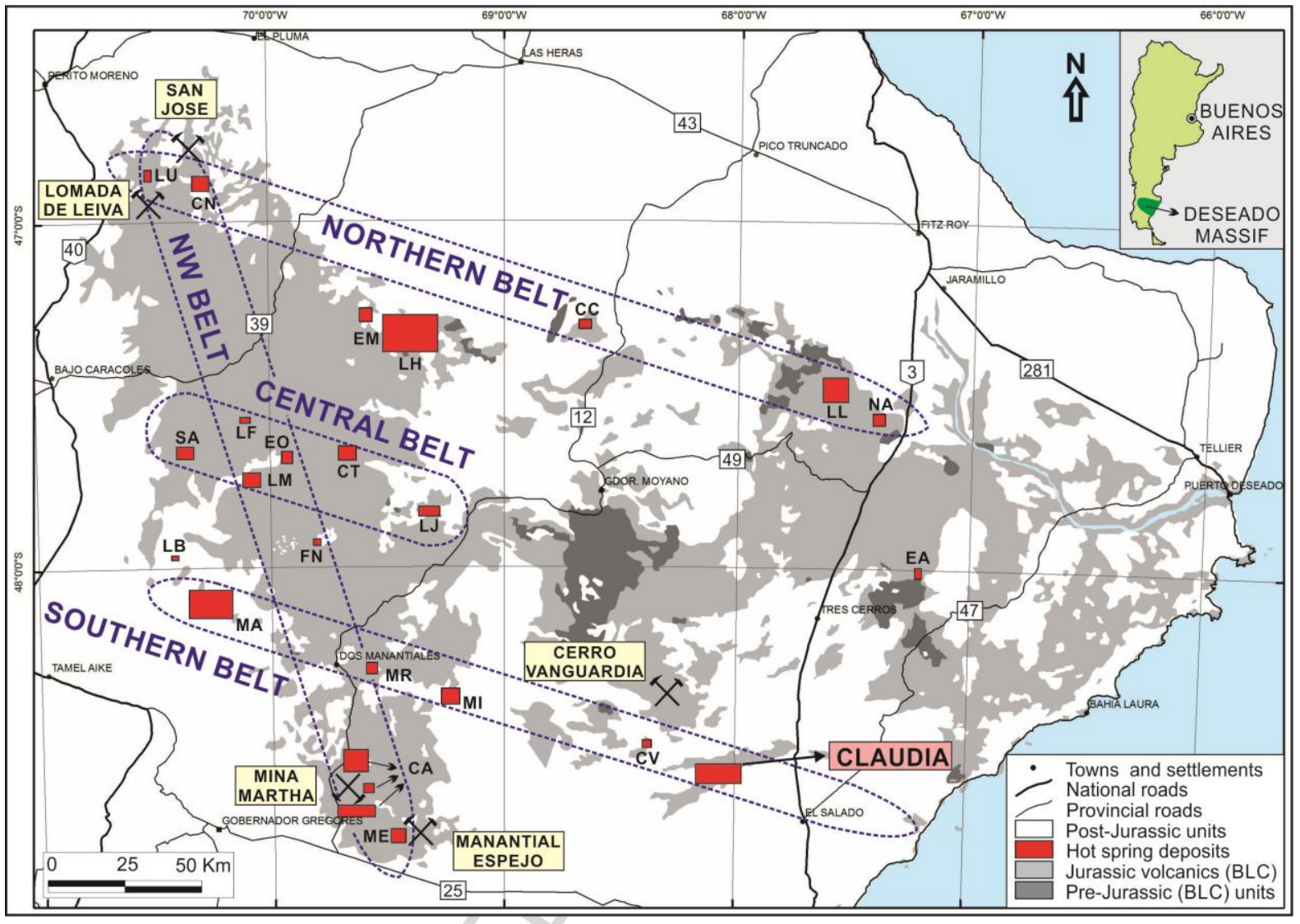

Figure 4 


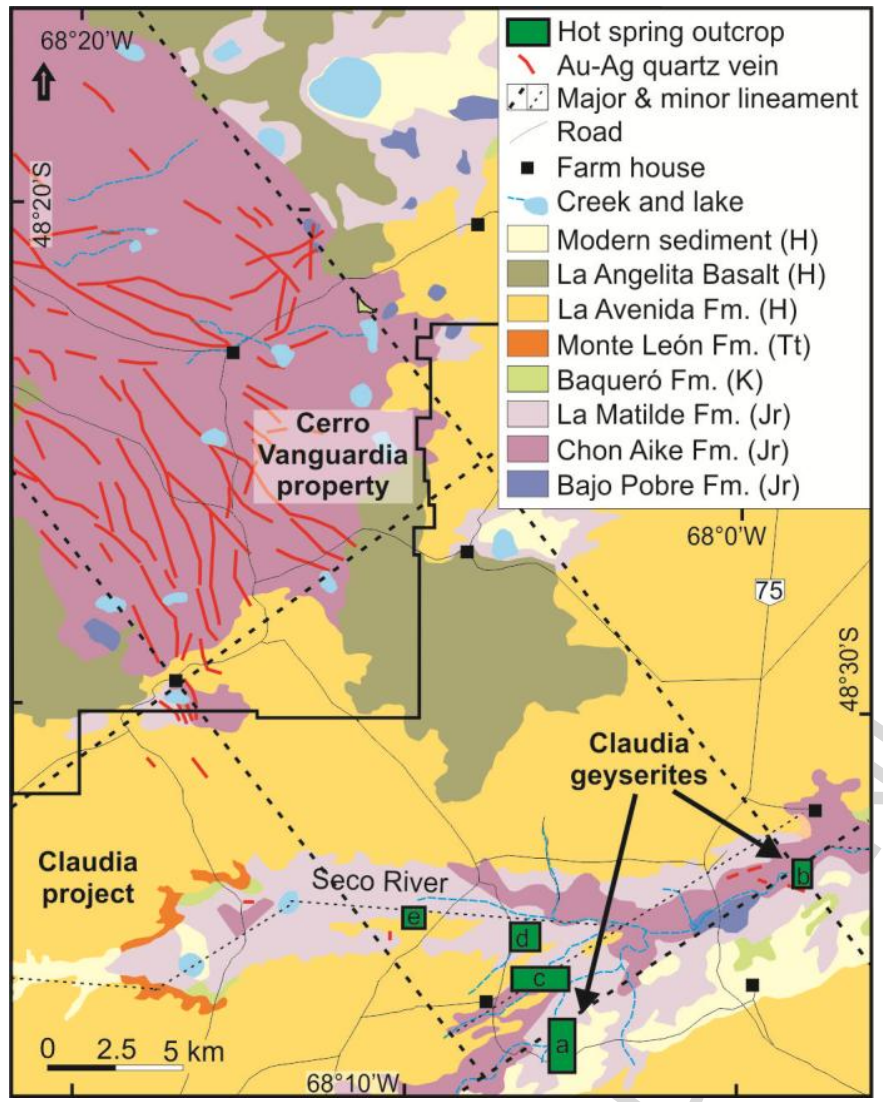

Figure 5 




Figure 6 


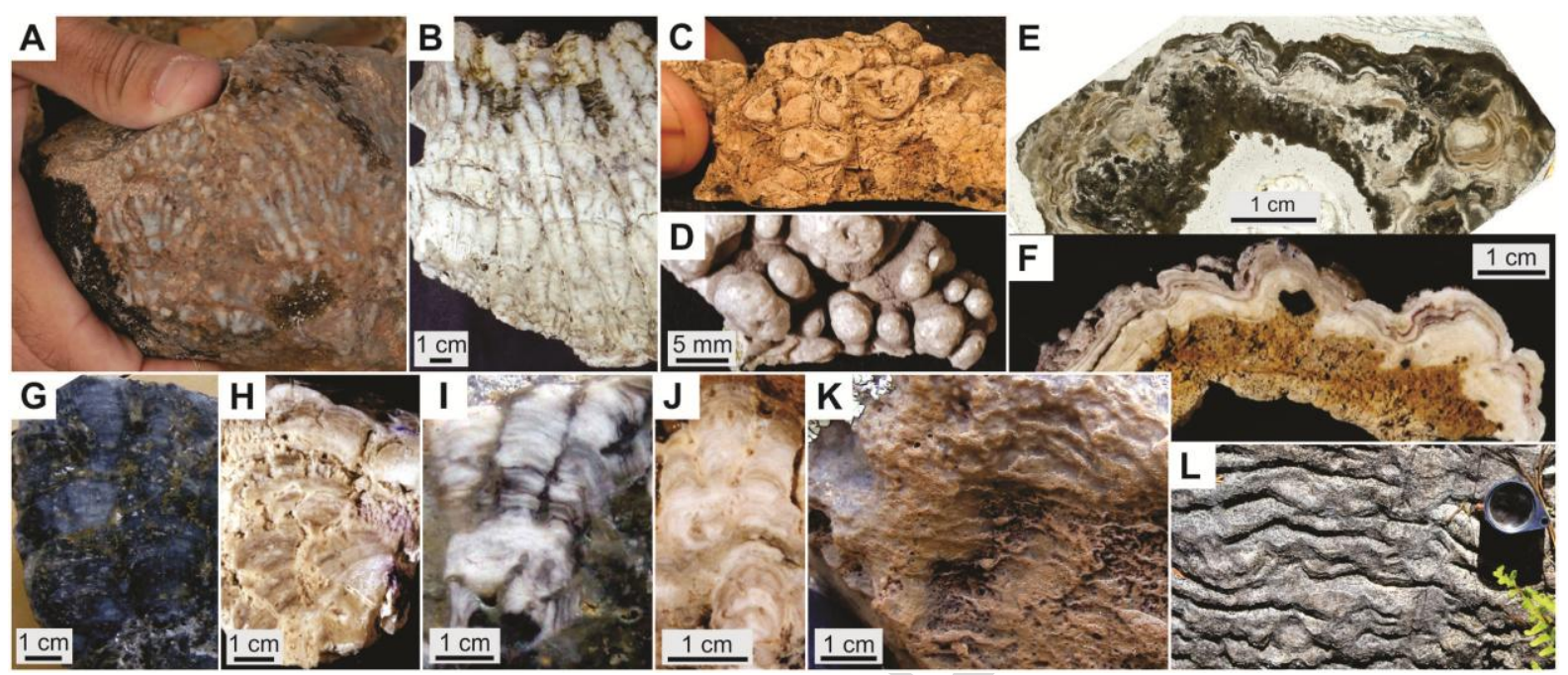

Figure 7 




Figure 8 


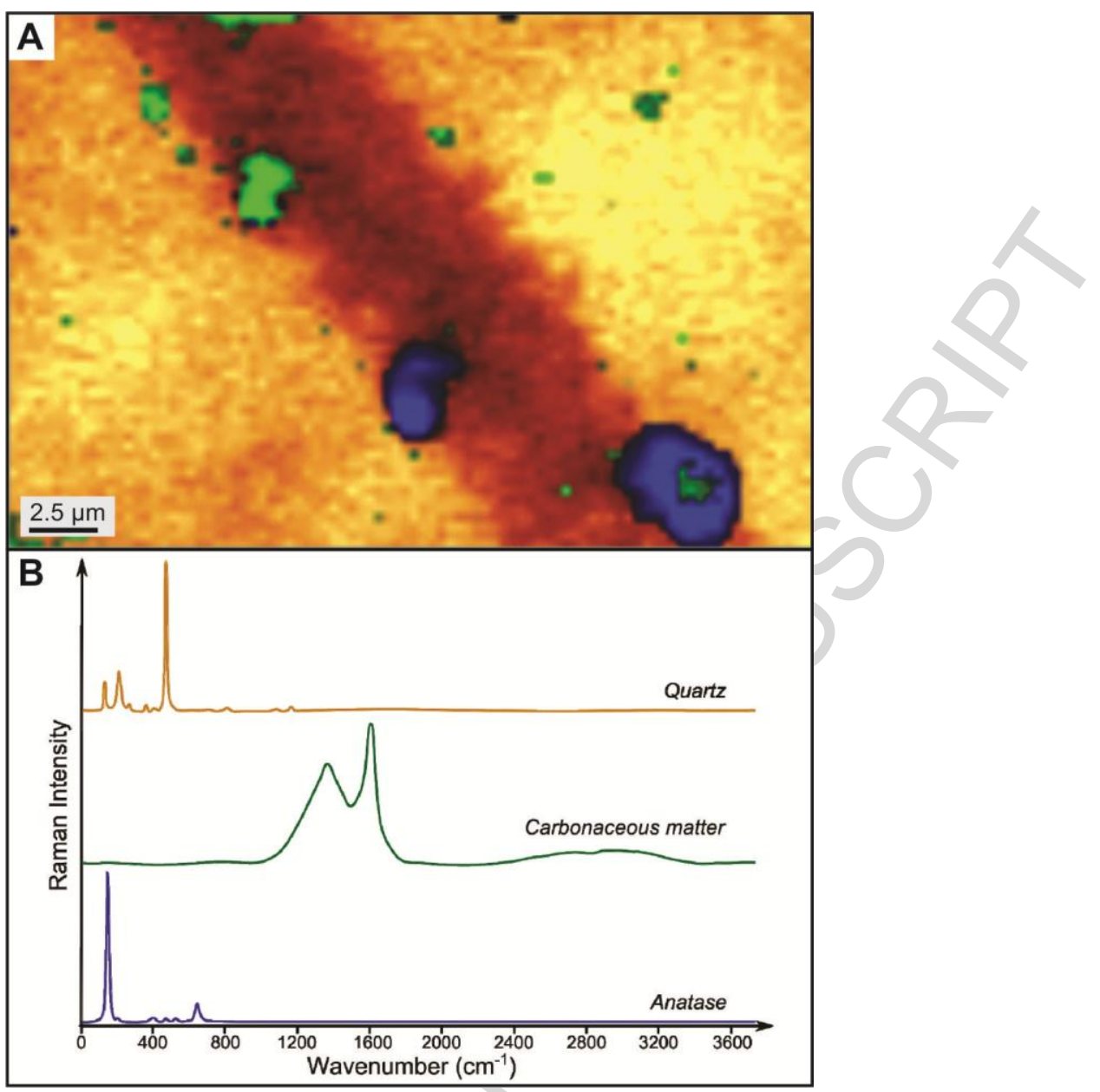

Figure 9 


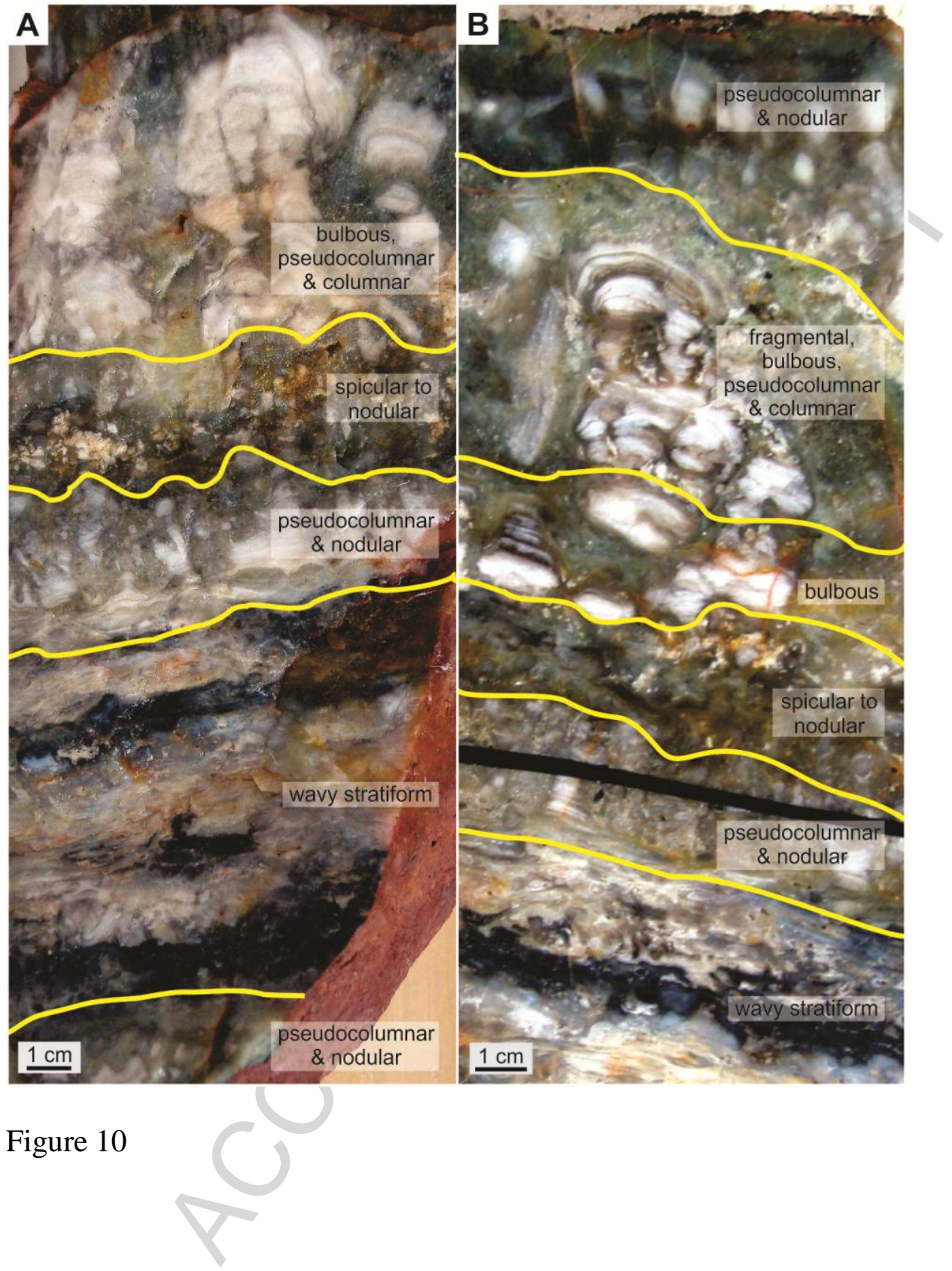




\begin{tabular}{|c|c|c|c|c|}
\hline $\begin{array}{l}\text { Facies } \\
\text { Assemblage }\end{array}$ & Facies & Geometry \& Textures & Microbial Fossil Association & $\begin{array}{l}\text { Sinterl } \\
\text { Travertine }\end{array}$ \\
\hline \multirow{11}{*}{ PROXIMAL } & \multirow{6}{*}{ Vent } & Conduit/Throat & & $\mathrm{S}, \mathrm{T}$ \\
\hline & & Breccia/Panal & 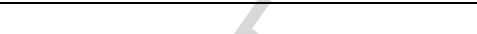 & $\mathrm{S}, \mathrm{T}$ \\
\hline & & Channel & $8>$ & $\mathrm{S}, \mathrm{T}$ \\
\hline & & $\begin{array}{l}\text { Spicular/Nodular/Botryoidal/Colum } \\
\text { nar/ Pseudocolumnar/Cumulate }\end{array}$ & tubular/filamentous biomorphs (this study) & S \\
\hline & & Beads & + & S \\
\hline & & Radiating macrobotryoids & -1 & $\mathrm{~S}, \mathrm{~T}$ \\
\hline & Proximal Slope & Fine lamination & 2 & S \\
\hline & Volcano-shaped Cone & Inclined bedding around conduit & Cauliflowers at base, biolaminites adjacent & $\mathrm{S}, \mathrm{T}$ \\
\hline & Concentric Cone & Crenulated concentric laminae & Stromatolite build-ups, merging into mounds & $T$ \\
\hline & Tubiferous Mounds & Radiating cylindrical larval cases & Encrusting cauliflowers on caddis fly tubes & $S$ \\
\hline & Mound/Terraces & $\begin{array}{c}\text { Concentric } \\
\text { macrobotryoids/bedded }\end{array}$ & nated pillars & $S, T$ \\
\hline \multirow{5}{*}{ MIDDLE } & \multirow{3}{*}{ Channel } & Wavy laminated 'bubble mats' & Lenticular voids interlayered with wavy mat laminae & $\mathrm{S}, \mathrm{T}$ \\
\hline & & Packed fragmental & Hot-water creek point bars of mat fragments & $\mathrm{S}, \mathrm{T}$ \\
\hline & & Streamer fabric & $\begin{array}{c}\text { Densely aligned on bedding planes, associated with } \\
\text { wavy laminated fabric }\end{array}$ & $\mathrm{S}, \mathrm{T}$ \\
\hline & \multirow[b]{2}{*}{ Mid Apron Pools } & Thin palisade lamination & $\begin{array}{l}\text { Comprising fine filaments in densely packed vertical } \\
\text { pillar structures }\end{array}$ & $\mathrm{T}$ \\
\hline & & $\begin{array}{l}\text { Network/Conical tufted/Ropy } \\
\text { folded }\end{array}$ & $\begin{array}{l}\text { Tufts vs. ropy fabric represent undisturbed vs. } \\
\text { disturbed growth in pools; networks around drying } \\
\text { pool margins }\end{array}$ & $S, T$ \\
\hline \multirow{8}{*}{ DISTAL } & \multirow{4}{*}{ Distal Apron } & Foam texture & & $S, T$ \\
\hline & & $\begin{array}{l}\text { Terracettes/Thick palisade } \\
\text { lamination }\end{array}$ & $\begin{array}{l}\text { Comprising coarse filaments in densely packed } \\
\text { vertical pillar structures }\end{array}$ & $S, T$ \\
\hline & & Low-amplitude wavy bedded & $\begin{array}{c}\text { Biolaminites interbedded with cross-bedded } \\
\text { sediments }\end{array}$ & $\mathrm{T}$ \\
\hline & & Spherulites/Oncoids & $\begin{array}{l}\text { Biolaminites and scattered filaments concentrically } \\
\text { accumulated }\end{array}$ & $\mathrm{T}$ \\
\hline & \multirow{4}{*}{ Marsh } & Fenestral & Clotted micritic matrix around small irregular voids & $T$ \\
\hline & & Mottled/Clotted/Peloidal & Clotted, fine-grained siliceous matrix & $\mathrm{S}$ \\
\hline & & Plants and/or animals & Encrusted with biolaminites & $\mathrm{S}, \mathrm{T}$ \\
\hline & & Paleosol & Weathered S fragments (some microbial) & $\mathrm{S}$ \\
\hline LACUSTRINE & Lakeshore Margin & HCS sandstone/Varved mudstone & Encrusting wavy crenulated fabric & $\mathrm{S}$ \\
\hline
\end{tabular}

Table 1 